\title{
Lousy and Lovely Jobs: the Rising Polarization of Work in Britain
}

\author{
Maarten Goos and Alan Manning
}




\begin{abstract}
This paper argues that skill-biased technical change has some deficiencies as a hypothesis about the impact of technology on the labor market and that a more nuanced view recently proposed by Autor, Levy and Murnane (2003) is a more accurate description. The difference between the two hypotheses is in the prediction about what is happening to employment in low-wage jobs. This paper presents evidence that employment in the UK is polarizing into lovely and lousy jobs and that a plausible explanation for this is the Autor, Levy and Murnane hypothesis.
\end{abstract}

JEL Classification: J210

Keywords: Labor Demand and Technology, Inequality

This paper was produced as part of the Centre's Labour Markets Programme. The Centre for Economic Performance is financed by the Economic and Social Research Council.

\title{
Acknowledgements
}

We would like to thank David Autor, Francis Green, Frank Levy and Coen Teulings for comments on this paper, and David Autor and Francis Green for making their data available.

Maarten Goos is an Occasional Research Assistant at the Centre for Economic Performance, London School of Economics. Alan Manning is a Programme Director at the Centre for Economic Performance and Professor of Economics, London School of Economics.

\section{Published by}

Centre for Economic Performance

London School of Economics and Political Science

Houghton Street

London WC2A 2AE

All rights reserved. No part of this publication may be reproduced, stored in a retrieval system or transmitted in any form or by any means without the prior permission in writing of the publisher nor be issued to the public or circulated in any form other than that in which it is published.

Requests for permission to reproduce any article or part of the Working Paper should be sent to the editor at the above address.

(C) M. Goos and A. Manning, submitted 2003

ISBN 0753016826

Individual copy price: $£ 5$ 


\section{Introduction}

Economists writing about the impact of technology on the labor market in recent years have tended to emphasize the role played by skill-biased technical change (SBTC), the idea that technology is biased in favor of skilled workers and against unskilled workers. The idea of SBTC has primarily been used to explain rising wage inequality (see Katz and Autor [1999] for a survey of a very large literature). But a recent paper by Autor, Levy and Murnane (ALM) [2003] has argued for a more nuanced way of understanding the impact of technology in general (and computers in particular) on the labor market ${ }^{1}$. They argue persuasively that technology can replace human labor in routine tasks, be they manual or cognitive, but (as yet) cannot replace human labor in non-routine tasks. The ALM hypothesis is intuitively plausible and they provide evidence that industries in which routine skills were heavily used have seen the most adoption of computers, and this has reduced the extent of routine skills in those industries (see Spitz [2003] for similar evidence for Germany). But, if the ALM hypothesis is correct then we might expect to see evidence for it in other areas: this is the aim of this paper.

The basic idea is the following. The SBTC hypothesis predicts that demand for 'skilled' jobs is rising relative to that in 'unskilled' jobs, while the ALM hypothesis suggests a more subtle impact of technology on the demand for labor of different skills. The routine tasks in which technology can substitute for human labor include jobs like craft manual jobs and book-keeping jobs that require precision and, hence, were never the least-skilled jobs in the labor market. The non-routine tasks which are complementary to technology include 'skilled' professional and managerial

\footnotetext{
${ }^{1}$ See also Card and DiNardo [2002] for the argument that SBTC is not as successful in explaining wage inequality as commonly thought.
} 
jobs but also many of the most 'unskilled' jobs such as shelf filling that rely on handeye coordination that virtually all humans find easy but machines find enormously difficult.

If this is true (and we provide evidence below that it is) then the impact of technology will be to lead to rising relative demand in well-paid skilled jobs (that typically require non-routine cognitive skills) and in low-paid least skilled jobs (that typically require non-routine manual skills) and falling relative demand in the 'middling' jobs that have typically required routine manual and cognitive skills - a process we call job polarization. This paper investigates whether the pattern of employment changes in Britain over the period 1975-99 is consistent with job polarization and the consequences of that.

There is an existing literature related to the idea of job polarization - the 'job quality' debate in the US. Some of the early papers on the rise in US wage inequality (e.g. Bluestone and Harrison [1988]) argued that there was an increasing number of low-wage jobs and a shrinking number of 'middling' jobs. This was controversial even at the time (e.g. see Kosters and Ross [1988]) and most labor economists came to the conclusion that the problem for low-skill workers was a declining number of jobs for them rather than an increasing number (see Burtless [1990]). But, in the 1990s one can still find a number of papers continuing to address the major themes of the job quality debate (see, for example, Costrell [1990], Howell and Wolff [1991], Levy and Murnane [1992], Juhn, Murphy and Pierce [1993], Murphy and Welch [1993], Gittleman and Howell [1995], Ilg [1996], Farber [1997], Acemoglu [1999, 2001], Juhn [1999], Ilg and Haugen [2000], Wright and Dwyer [2003]). Although these studies do differ slightly in their conclusions, common themes do emerge, most notably that, in the last 30 years, there has been a very big increase in the number of 
high-paid jobs and (probably) an increase in the number of low-paid service jobs this is broadly consistent with the job polarization prediction of the ALM hypothesis although few of these papers give this interpretation.

The plan of the paper is as follows. In the first section, we use the US data from Autor, Levy and Murnane [2003] to show that the jobs that require non-routine tasks tend to be at the top and bottom of the wage distribution while the jobs that require routine tasks tend to be in the middle, thus leading to the job polarization prediction. The second section describes the data used for the UK. The third section then documents how job polarization can be observed in the UK between 1975 and 1999 when the quality of jobs is defined by their median wage. There has been a growth in lousy jobs (mainly in low-paying service occupations) together with a (much larger) growth in lovely jobs (mainly in professional and managerial occupations in finance and business services) and a decline in the number of middling jobs (mainly clerical jobs and skilled manual jobs in manufacturing). We document that one sees these trends using all measures of employment, for men and women together or separately and for all definitions of 'jobs' that we use. The fourth section considers an alternative way to look for evidence of job polarization previously used by Juhn, Murphy and Pierce [1993] and Juhn [1999] that predicts employment growth at each percentile of the wage distribution. There is evidence of job polarization using this approach as well.

As this conclusion is not in line with the predictions of the SBTC hypothesis, sections five and six consider the evidence most commonly cited in favor of that hypothesis. Section five considers the rise in the employment of non-manual workers - we argue that the pattern of within and between industry changes in employment observed at the 1-digit occupation level is consistent with the ALM hypothesis that 
technical progress has displaced the labor of clerical and manual workers in all sectors of the economy but that differential productivity growth between manufacturing and service sectors has led to the growth in low-wage service employment (as originally proposed by Baumol [1967]).

Section six documents that the well-known shift towards more educated labor has largely occurred within jobs and that there has been a rapid rise in educational attainment of workers even in the worst jobs. There are two possible interpretations of this. First, that there has been SBTC within jobs as we define them so that the consensus view on the importance of SBTC is correct. Secondly, that as the educational attainment of all groups in the population has risen but the job distribution has become more polarized, some educated workers are forced into the low-skill jobs at the bottom end of the distribution. The attraction of this view is that it can explain why there has been a simultaneous rise in the returns to education (the demand for educated workers has risen as the number of good jobs has increased) and in the level of over-education as some have claimed. Distinguishing between these hypotheses requires evidence on changing skill requirements within jobs that is hard to find. We review two pieces of evidence that might shed light on these questions although they are somewhat contradictory in their implications.

The seventh section considers the extent to which the observed job polarization can explain the rise in wage inequality between the 1970s and 1990s. We find that a modest part of the rise in wage inequality can be explained by the polarization of jobs alone but that once one includes the fact that wage growth seems to be monotonically positively related to the quality of jobs one can explain most of the evolution of wage inequality. The implication is that the rise in 'within-group' wage inequality that others have emphasized is more a product of a restricted 
definition of a 'group' and that if one includes job controls then it largely disappears. However the finding that the wages in the lousy jobs are falling relative to those in the 'middling' jobs presents something of a problem for the ALM hypothesis as one might expect the opposite if relative demand is rising in the lousy relative to the middling jobs.

Section eight investigates whether supply-side factors, the changing composition of the labor force, notably the increasing importance of female labor, can explain part of job polarization. The answer is 'no'. The final section concludes.

\section{Routine Jobs, Non-routine Jobs and Technical Change}

In this section we show how the Autor, Levy and Murnane [2003] view of the impact of technology on the demand for different skills predicts job polarization. ALM use the US Dictionary of Occupational Titles (DOT) to associate particular occupations with the intensity of use of five particular types of task. The types of task included in the analysis are chosen to represent those that are affected in different ways by technology - they label them non-routine cognitive, non-routine interactive, routine cognitive, routine manual and non-routine manual (see Autor, Levy and Murnane [2003] for a more detailed description of the tasks given these labels).

ALM then show that industries that were relatively intensive users of occupations that use routine tasks had more computerization and that the extent of the use of routine skills has fallen in these industries. Here we pursue an angle of the ALM hypothesis that ALM do not develop - namely that jobs that can be routinized are not distributed uniformly across the wage distribution. The central idea is that non-routine manual jobs are concentrated in the lower percentiles of the wage distribution whereas non-routine cognitive and interactive jobs are concentrated in the 
top end of the wage range with routine jobs concentrated in the middle. As a result, technological progress can be expected to result in job polarization with employment growth in lovely and lousy jobs and employment falls in 'middling' jobs.

Table I presents a simple way of showing that the non-routine jobs are concentrated at the top and bottom of the wage distribution. We use wage information from the CPS MORG 1983 file and assign to each individual the five task measures in 1977 used by ALM based on their occupations ${ }^{2}$. All skills are measured on a 10-point scale, although these should not be taken to be comparable across tasks. Table I tabulates the fraction of workers that have DOT scores above the overall mean DOT score for the 5 different tasks as a percentage of total employment within the three terciles of the wage distribution. For example, only $17 \%$ of all workers in the lowest paid occupations are in jobs that require above average non-routine cognitive skills. But $88 \%$ percent of workers in the highest paid occupations are in jobs that require above average non-routine cognitive skill. A similar picture holds for the nonroutine interactive skills: occupations intensive in non-routine interactive skills are concentrated in the right tail of the wage distribution. In contrast, routine intensive occupations are concentrated in the middle. Of workers in occupations earning between the $33^{\text {rd }}$ and $66^{\text {th }}$ wage percentiles, $63 \%$ require above average routine cognitive and $58 \%$ above average routine manual skills. These numbers are higher than for any other specified wage range. Finally, the lowest paid occupations require a higher fraction of non-routine manual skills and its fraction is higher than for any other occupation paying higher wages.

This section has shown some direct evidence that workers in the middling jobs used to do routine tasks, while workers in lousy and lovely jobs do non-routine tasks.

\footnotetext{
${ }^{2}$ We are grateful to David Autor for making the DOT data available to us. The year 1983 is the earliest year for which the DOT occupations can be merged into CPS data.
} 
Since non-routine jobs are concentrated in both tails of the wage distribution, the ALM hypothesis predicts an increasing polarization of the workforce into lousy and lovely jobs. This predicted process of polarization provides an explanation for the empirical "facts" in an ongoing debate about the quality of jobs mentioned in the introduction.

\section{The Data}

The main data in this paper comes from Britain but we would expect the task composition of occupations and the impact of technology to be very similar to that observed in the US. The data used in this paper come from two sources, the New Earnings Survey (NES) and the Labor Force Survey (LFS). The New Earnings Survey is an annual panel dataset that started in 1968 though the first year for which computerized records are available is 1975 , the sample being all individuals whose National Insurance number ends in '14'. In April of each year the tax records are used to contact the employer of each of these workers who reports information on pay, hours, and, importantly for this paper, occupation and industry. Although the NES is in theory a random sample, it is known to under-sample certain groups in practice, notably part-time workers (if weekly earnings fall below the threshold for paying National Insurance then they are unlikely to appear in the tax records) and those who have changed jobs recently (as the sampling frame is drawn up early in the year and the survey is likely to be sent to the wrong employer in April).

For this reason we supplement the NES with data from the Labor Force Survey. The LFS was first conducted in 1975 , then every two years until 1983, then annually until 1992 and quarterly since then (when a panel component was also introduced). The LFS has a much smaller sample than the NES (and until 1993 it did 
not contain any wage data) but does have the advantage that it is closer to a random sample.

In this paper we define a 'job' as a particular occupation or as a particular occupation in a particular industry. The occupation part corresponds to the main usage of the term 'job' - the question in the LFS used to obtain the information on occupation is 'what was your main job in the week ending Sunday?'. The industry part of the definition of a job is more problematic but other papers in this area have used a similar definition and there are significant industry effects on wages even once one has controlled for occupation. However, it is important to realize that the occupation part of our definition is much more important than the industry part as one gets very similar results whether a job is defined by occupation alone or by an occupation-industry interaction.

We have explored using different levels of disaggregation by occupation and industry and the results seem robust to the level chosen. We have restricted the results reported in this paper to using 3-digit occupation codes only (allowing for approximately 370 jobs) as well as the interaction of a 3-digit occupation and 1-digit industry classification (allowing for a maximum of 3700 jobs, although in practice only about 1600 exist as not all occupations are represented in all industries). One might wonder about whether there are jobs that are disappearing and new ones popping up. In practice this does not seem to be a problem: of the occupations that existed in the 1970s all still have workers in them in the late 1990s and there are essentially no new occupations that cannot be put into the 1970 s classification. 


\section{Trends in the Quality of Jobs}

We start by looking at long-term trends in the quality of jobs. To do this, obviously requires a measure of the quality of a 'job'. We do this in a very simple way by using the median wage in the job at the beginning of the period (see OECD [2001] and Meisenheimer [1998] for a discussion of other ways of discussing the quality of jobs). One can think of it as a 'single-index' model of skill - see Card and Lemieux [1996]. However, the next section takes a slightly different approach based on the analysis of Juhn, Murphy and Pierce [1993] with very similar results.

First consider how the proportional change in employment from the mid1970s to the mid-1990s is related to the initial level of wages. If the SBTC hypothesis is correct then one would expect to see a monotonic positive relationship between employment growth and initial wages. Figure I groups occupations into the 'lowest $10 \%$ ', the 'second-lowest $10 \%$ ', up to the 'top $10 \%$ ' based on their median wage and cell size in 1979. For example, the worst job quality decile captures $10 \%$ of all workers employed in the lowest paid occupations. Figure I shows large growth in the share of employment in the top two deciles, but also growth, albeit smaller, in the share of jobs in the bottom decile. Also, there has been a significant decline in middling jobs. Though the increase in the number of workers with bad jobs has been less relative to the increase in workers with good jobs, employment polarization into low paid and high paid work is clear from Figure I. It is this process of job polarization that is the central theme of this paper.

Figure II presents the LFS data for the period 1979-99, where the size of the circles denotes the initial employment level in each occupation. There is certainly no striking evidence of a positive monotonic relationship between employment growth and initial log median wages as the literature on SBTC might have led one to expect. 
And, one can discern the J-shaped relationship that is going to appear in the regression results. On Figure II, we also include a kernel regression estimate of the mean of employment growth conditional on job quality. ${ }^{3}$

Figure I and Figure II relate to one measure of employment, one definition of a job and to one survey (the LFS). One would like to know whether the results are robust or not. Because it is tedious to present graphs for every possible outcome, we turn to a regression way of presenting our results.

\section{Regression estimates}

The models we estimate are of the quadratic form:

$$
\Delta n_{j}=\beta_{0}+\beta_{1} w_{j 0}+\beta_{2} w_{j 0}^{2}
$$

where $\Delta n_{j}$ is the change in log employment in job $\mathrm{j}$ and $w_{j 0}$ is the initial log median wage in the job.

We experiment with a number of different measures of employment and jobs. Table IIa presents estimates combining employment for men and women. The top half of Table IIa measures employment in terms of bodies using different definitions for a job and different surveys: we report results from the LFS and the NES using either 3-digit occupation codes only or the interaction of a 3-digit occupation code with a 1-digit industry code. But the results tell a similar story. The linear term in (1) is negative and the quadratic term positive implying a U-shaped relationship between employment growth and the initial level of wages. One might be concerned that the downward-sloping part of this relationship contains no data points but, as the final column in Table IIa makes clear, this is not the case: substantial numbers of workers

\footnotetext{
${ }^{3}$ These are Nadaraya-Watson estimates, using a bandwidth of 0.1 and an Epanechnikov kernel.
} 
are in the downward-sloping part of the relationship ${ }^{4}$. These regressions support the view that there has been polarization in the quality of jobs, with the employment growth being at the extreme ends of the distribution. It should also be noted that the parameter estimates for the LFS and NES are very similar, which suggests that the non-random sampling in the NES is not too serious a problem. We have also experimented with further aggregation or disaggregation in the jobs classification but this does not seem to make a great deal of difference to the qualitative results.

One might think that these results are misleading because much of the growth in employment has been in part-time jobs and these tend to be low-paid. Hence, the estimates in the top half of Table IIa might be thought to over-state the employment growth in low-paid occupations. However, when we measure employment in terms of total hours, the results are very similar so this does not explain away the observed job polarization.

One might also think that the feminization of employment can explain this job polarization, with women accounting for the growth in relatively low-paid occupations. But, as Table IIb and Table IIc show, one observes similar patterns for male and female employment considered separately although the trends are more marked for men. ${ }^{5}$

One might also be concerned that the quality ranking of jobs changes a lot over time so that the patterns of employment growth are sensitive to the point in time at which job quality is measured. Table III shows this is not the case: one gets similar results if one uses median wages at the end of the period to rank jobs. This reflects the well-known fact that there is very considerable stability in the occupational wage structure.

\footnotetext{
${ }^{4}$ Inspection of the kernel regression line in Figure II should make it clear that this estimate of the proportion in the downward-sloping section is not an artifact of the quadratic specification adopted. ${ }^{5}$ Note that the last column in Table IIc shows a missing if the U-shape is not significant.
} 


\section{Employment Growth by Occupation}

What are the sorts of jobs that are growing and declining? Table IV presents a 'top 10' by job growth for occupations that have cells of a respectable size using the LFS data. The first column specifies the occupation. Since growth in the best jobs has been stronger than employment growth in the bad jobs, most of the jobs reported in Table IV pay above median hourly wages as can be seen from the second column in the table. Columns three and four report estimated employment levels by occupation whereas the final column calculates the percentage change in employment between 1979 and 1999.

Rapidly growing lovely jobs are specialized occupations mainly in finance and business service industries located at the top end of the wage distribution. Positions 1, 6 and 7 in the 'Top 10' however are taken by low paid jobs. Among these, the biggest growth in absolute numbers was in care assistants and attendants but there has also been a strong percentage increase in educational assistants and hospital ward assistants. Moreover, just outside the top-10 one finds large increases in the number of nursery nurses, hotel porters, merchandisers, window dressers and travel and flight attendants, among other low-paid service occupations.

Given the emphasis in the literature on SBTC the presence of the good jobs in Table IV is probably no surprise but the bad jobs might be more surprising. However, this pattern is exactly what we would expect to see according to the ALM hypothesis as the rapidly-growing lousy jobs are all ones where it has proved difficult to substitute machines or computers for human labor. To get a better idea of employment changes in the worst jobs, Table $\mathrm{V}$ lists the 10 lowest paying jobs given they are of considerable size, their median wage and employment in 1979 and 1999. 
The biggest absolute increase in those jobs listed has been for sales assistant and checkout operators.

To see further evidence supportive of the ALM hypothesis Table VI lists the bottom 10 jobs by job growth. A comparison of the median job wages with the overall median suggests the decline in jobs has been largest for middling jobs in manufacturing occupations.

In sum, between the 1970s and late 1990s we have seen rapid employment growth in lovely jobs (mainly in professional and managerial occupations in finance and business services), some growth in lousy jobs (mainly in low-paying service occupations) and a decline in the numbers of middling jobs (mainly clerical jobs and skilled manual jobs in manufacturing).

\section{An Alternative Approach}

So far we have defined the quality of a job by the median wage in that job. Although this approach has the virtue of simplicity in that it enables us to label specific jobs as 'good' or 'bad' it does ignore the fact that there is substantial wage dispersion within jobs. One approach to dealing with this is taken by Juhn, Murphy and Pierce [1993] - although that paper is better known for other contributions - and Juhn [1999].

They assume that each job (defined here as an occupation) potentially uses labor from each percentile of the wage distribution. They compute the share of labor from each percentile used in each job in a base year. Assuming that these 'factor shares' remain constant, one can then predict changes in employment for each percentile of the wage distribution by allowing changes in the total levels of employment in each occupation. Note that now the same job potentially contributes to 
the predicted change in employment for each percentile rather than contributing only once as in the single-index approach taken in the previous section.

Figure III plots these predicted employment changes between 1976 and 1995 for different percentiles of the 1976 wage distribution. As Figure III shows, employment growth is positive for all workers earning less than the $11^{\text {th }}$ percentile and more than the $86^{\text {th }}$ percentile. Predicted growth at the top end is strongest, between $35 \%$ and $45 \%$. Growth at the $5^{\text {th }}$ percentile is between $8 \%$ and almost $20 \%$ percent whereas employment in the middling jobs is in decline. The conclusions derived are therefore the same as those derived from our more simplistic approach in the previous section that there has been increased polarization in the quality of jobs. It is noteworthy that only in the top 3 deciles does one see evidence of the positive relationship between skill and employment change as predicted by SBTC.

The evidence of job polarization presented in this and the previous section are supportive of the ALM view of the impact of technology on the demand for labor as opposed to the SBTC hypothesis. But, we need to understand the evidence that is often quoted in support of SBTC and the next two sections consider two of these - the growth in non-manual employment and the rise in the educational attainment of the workforce.

\section{Understanding the Growth in Non-Manual Employment}

A number of papers (e.g. Berman, Bound and Griliches [1994], Berman, Bound and Machin [1998], Machin and Van Reenen [1998]) have presented evidence that employment has shifted towards non-manual jobs and that this shift has been much more important within than between manufacturing industries. As non-manual

jobs tend to be better than manual jobs this is interpreted as evidence that technical 
change is biased towards more skilled workers. And the fact that most of the shifts are within industries suggests that this trend is related to technical change that has very pervasive effects on all sectors of the economy. As a statement about the average quality of jobs, this conclusion is undoubtedly right: our data also suggests that the 'average' job quality is increasing. But the simple binary distinction between manual and non-manual is simply not able to capture the increased polarization we have also argued is important ${ }^{6}$.

If the shift-share analysis is done for broader occupation groups and for the whole economy, not just manufacturing, we get the results presented in Table VII. For each occupation Table VII reports a manual/non-manual indicator taken from the LFS ( $M$ or $N M$ respectively). Occupations are ranked by their median wage. Then, for each of the two data sets, the first column reflects the total percentage point change in the share of each occupation group between 1979 and 1999. The second column measures the percentage point change due to changes within industries whereas the final column reports the change due to workers moving between industries.

The results are rather more nuanced than earlier studies would suggest and in line with the ALM hypothesis. There is a large increase in the employment shares of managerial and professional workers, an increase in lovely jobs that is mostly 'within' industries. Both craft workers and machine operatives have large negative within and between components reflecting both the impact of technical change and the shift towards services. Routine clerical occupations have large negative employment effect within industries together with a sizeable positive 'between' component reflecting the shift to services. The increase in the employment share of low-paid personal and

\footnotetext{
${ }^{6}$ Indeed any binary distinction between low- and high-skill workers (whether in theoretical or empirical work) cannot have separate mean and variance effects.
} 
protective services and sales occupations has a large within and between component reflecting the fact that technology has not managed to do these jobs and the shift toward services.

Therefore studies that use a simple manual/non-manual split (usually out of necessity rather than choice) and concentrate on manufacturing miss important features of the way the structure of employment is evolving. If one broadens one's view then one does see evidence for the ALM hypothesis.

\section{Education and Occupation}

Another piece of widely cited evidence in favor of the SBTC hypothesis is that there has been a rapid increase in the level of educational attainment together with a rise in the returns to education. It is true that there is a lot of evidence that the average educational attainment of workers within jobs has changed. One way of seeing this is Figure IV which uses the LFS to compute the fraction of workers that have education at ' $A$ ' level or above in the 1970 s while re-weighting by the change in employment across occupations to predict the demand for educated workers if there had been no education up-grading within occupations. ${ }^{7}$ These predicted changes are much less than those actually observed suggesting an increase in educational attainment within jobs.

The top panel of Figure $\mathrm{V}$ plots the fraction of workers with 'A' levels or a higher degree in each job in 1979. Clearly, the fraction increases when one moves to

\footnotetext{
${ }^{7}$ This re-weighting procedure gives the counterfactual mean in a familiar Oaxaca-Blinder decomposition of the probability of having 'A' levels (or above) explained by an exhaustive set of occupation dummies. Lemieux [2002] labels this procedure "a unifying approach", combining elements from both Juhn, Murphy and Pierce [1993] (by constructing counterfactuals for the dependent variable at the individual level) and DiNardo, Fortin and Lemieux [1996] (by re-weighting observations). According to Lemieux [2002], the advantage of re-weighting individual observations is that its use need not be limited to estimating counterfactual means but can be applied to estimating any moment of the counterfactual density of the dependent variable. Indeed, in Section VII we use a similar unifying approach to construct counterfactual percentiles of the wage distribution.
} 
higher percentiles of the wage distribution. The bottom panel of Figure V looks at the percentage point change in the fraction of 'A' level (or above) workers in each job between 1979 and 1999. It is noticeable that educational up-grading has occurred among all jobs.

There are two interpretations of these findings. First, that what we have defined as a 'job' is not constant over time and the educational and/or skill requirements within jobs has risen possibly because of SBTC within jobs. Secondly, that as the educational attainment of the labor force has increased and middling jobs become relatively scarcer some educated workers have been forced to take lousier jobs than previously - this is the idea of the literature on over-qualification (see, for example, Sicherman [1991], Hartog [2000] and, for the UK, Green et al. [1999], Chevalier [2000] and Green and McIntosh [2002]) that typically finds that high proportions of people report that they are employed in jobs for which their educational qualifications are unnecessary. Employers may also respond by raising the minimum educational standards to get certain jobs - what is known as credentialism. To distinguish these two hypotheses requires some information on changes in skill use within occupations. This is not so easy to find but we present two pieces of disparate information relevant to the question.

First, consider the data on the use of the five DOT measures used by Autor, Levy and Murnane [2003]. Table VIII presents data on the average level of skill use in 1977 , the change from 1977 to 1991 and the decomposition of this change into a within-occupation and a between-occupation component. Panel A of Table VIII pools all occupations together and shows an overall increase in non-routine cognitive and interactive tasks together with a decrease in routine tasks (especially cognitive ones) and a smaller decrease in non-routine manual tasks. But, the decomposition suggests 
that, within occupations, there is only a rise in the non-routine interactive task and all other skills show declines, the decline being particularly large for the routine cognitive task.

From the point of view of educational up-grading it is what is happening in the lousy jobs that is perhaps of more interest. Panel B does the same exercise for jobs in the bottom half of the wage distribution. Again one sees a big rise in the non-routine interactive task and large declines in routine tasks. But, most of the increase in skill requirements is between-occupation: within-occupation task requirements are generally falling. There is little evidence here that there is substantial SBTC within occupations (Spenner [1983] reaches similar conclusions).

Our second piece of evidence on changing skill requirements within occupations comes from the UK Social Change and Economic Life Initiative (SCELI) survey conducted in 1986 and the 2001 Skills Surveys ${ }^{8}$. Both of these surveys asked workers about the educational qualifications necessary to get the job they do and were then also asked whether these qualifications were necessary to do the job. Only data at 1-digit occupation level are comparable in the two datasets. Table IX presents some relevant information. The second column gives the change from 1986 to 2001 in the educational qualifications needed to get a job where qualifications are measured on a 5-point scale with 1 representing no qualifications and 5 a college degree. In all occupations there is a rise in the level of qualifications required, with a very large rise in sales occupations and elementary occupations. This could reflect greater skill requirements within occupations or a greater use of credentialism. There is evidence (shown in the third column) that more workers report in 2001 that the education required to get the job is not necessary to do the job but, in the absence of any

\footnotetext{
${ }^{8}$ We are grateful to Francis Green for doing these computations for us.
} 
information on the extent to which education is under-utilized, one cannot know whether this effect is large enough to outweigh the positive effect on skill levels of an increase in the level of education required. Felstead, Gallie and Green [2002] also report that learning times are increasing within jobs.

These two pieces of disparate evidence are not entirely consistent. The DOT data do not suggest any significant skill up-grading within occupations, while the SCELI/SS data suggest an increase in the level of education required by employers although also an increasing proportion of workers reporting that this education is unnecessary to do the job. But, it does seem that the supply of skills may be increasing faster than the demand in the bottom half of the distribution because the extent of over-qualification does not seem to be falling over time and, according to some estimates (e.g. Felstead, Gallie and Green [2002]), is actually increasing. ${ }^{9}$

Consistent with this, Felstead, Gallie and Green [2002] report that there is excess demand for workers with no qualifications, an excess supply of people with low-level qualifications and a rising use of credentialism among the lowest-level occupations.

\section{How Much of the Rise in Wage Inequality Can be Explained by Job Polarization?}

\section{Rising Wage Inequality and Employment Polarization}

All the analysis so far has been about the quantity side of the labor market - what is happening to the employment of different types of workers. But, the polarization of

\footnotetext{
${ }^{9}$ It has always been something of a puzzle to reconcile these findings of widespread over-qualification with rising employment and relative wages of educated workers. Our finding of increased job polarization can explain why both phenomena may co-exist. The increased supply of skills that has been necessary to meet the increased number of lovely jobs poses a problem for the increased number of lousy jobs. Because there has been an increase in the mean but no increase in the variance of educational qualifications, those in lousy jobs are increasingly likely to have higher levels of education than necessary for doing the job.
} 
employment could also be expected to have led to increased wage inequality. Of some interest is what fraction of the rise in wage inequality can be explained by this polarization of employment. This is the subject of this section.

In Figure VI we present the evolution of two actual measures of wage inequality over the period 1976-1995, the $\log (90 / 50)$ and the $\log (50 / 10)$ differentials, as well as a prediction of what would have happened if the only change in the wage distribution taking place is the change in the distribution of jobs in the economy. To this end we assign everyone in the base year (here, 1976) a weight that is equal to the total number of workers in a job in a given year divided by the job cell size in the initial period. We then compute counterfactual percentiles of the re-weighted wage distribution.

As is well-known actual wage inequality rose very strongly in this period following a fall in 1977 (the result of the 'Social Contract' incomes policy then in place). The rise in inequality is somewhat larger at the top of the distribution than at the bottom. Since the counterfactual log median increases only very little, the rises in the counterfactual $\log (90 / 50)$ and $\log (50 / 10)$ reflect large polarization. In comparison with the actual changes, increased job polarization can explain $33 \%$ of the increase in the $\log (50 / 10)$ differential between 1976 and 1995 and 54\% of the increase in the $\log (90 / 50)$ wage differential. It should also be noted that this process of polarization seems relatively smooth throughout the period: one cannot readily identify subperiods in which all the change occurred.

The remaining rise in wage inequality can be thought of as coming from one of two sources: differential changes in median wages across jobs and within-job wage inequality. For example, wage inequality will rise if median wages have risen faster in good jobs than bad jobs. The other potential source of increased wage inequality is 
an increase in within-job pay dispersion. To look for evidence of this Table X reports regression estimates of median wage growth onto the log of the initial median wage ${ }^{10}$. Since estimates will be biased downwards when using the initial wage on both sides of the regression equation, we use the NES and run regressions using wages in 1977 (rather than 1976) as a covariate. All point estimates are positive and all are statistically significant. These results suggest allowing median wages to change over time while keeping the variance of pay within each job constant could close the actual-counterfactual gap further.

The implications for wage inequality are presented in Figure VII. Here, we do the re-weighting described earlier and also adjust wages in every job cell by the change in log median wage in that cell. Now $51 \%$ of the increase in the $\log (50 / 10)$ differential between 1976 and 1995 and $79 \%$ of the increase in the $\log (90 / 50)$ wage differential can be explained.

\section{Within and Between Group Wage Inequality}

One implication of this is that the rise in within-job wage inequality has a relatively minor part to play in explaining the overall rise in wage inequality. This is in contrast with some studies that try to explain wage inequality in terms of age and education that typically find that most of the rise in inequality is due to rising withingroup wage inequality (see Levy and Murnane [1992] and Katz and Autor [1999] for a survey of the US literature and Machin [2003] for the UK). The studies are correct given the variables they use to try to explain the rise in wage inequality but the evidence here suggests that this conclusion is sensitive to how the groups are defined. Unfortunately, a small industry has been established based on the premise that wage

\footnotetext{
${ }^{10}$ We experimented with the inclusion of a quadratic term but this was never significant.
} 
inequality has risen very markedly among 'identical' workers and has been building theoretical explanations of this 'fact'.

One particularly simple way to understand this is to consider what is happening to the $R^{2}$ in earnings functions. Figure VIII graphs the $R^{2}$ from an earnings function estimated for each year on the NES in which the dependent variable is log hourly earnings, and the covariates include a complete set of dummies for age, industry and occupation, all interacted with gender. There are two things to note: first the $R^{2}$ is high - averaging almost two-thirds - compared to the one-third found in a standard specification using the US CPS. Secondly, there is no marked trend in the $R^{2}$ over time if one also includes the most recent years for which data are available (we believe this is also true for the US CPS, see for example Lemieux [2002]). The consequence is that the rise in the residual variance can explain only $1 / 3$ of the total rise of the variance in log wages.

The conclusion that the importance of within-group wage inequality depends on the controls one includes in an earnings function seems also consistent with US studies that have more detailed controls than is usual in earnings functions. For example, Dunne et al. [2000] have controls for establishment fixed effects (which are obviously better than industry) and find they can explain much of the rise in wage inequality by widening between-plant wage gaps. It seems likely that much of these wage gaps between plants can be explained in terms of the characteristics (in gender, age, education and occupation) of the workers within them - for example Hellerstein at al. [1999] find that a fairly rudimentary set of controls (less than 30) can explain $40 \%$ of the variation in average wages across establishments.

\section{Explaining Relative Wage Changes}


It is relatively easy to explain why wages at the top of the distribution have been increasing relative to the median as an increase in the demand in good jobs that has not been matched by an increase in supply. But, it is not clear why the increase in the demand for bad jobs has not resulted in a rise in wages at the bottom relative to the median. The rise in the number of bad jobs has coincided with a decline in their pay not just relative to the good jobs that are increasing in number but also relative to the middling jobs that are decreasing in number. If the labor market is competitive this does not seem consistent with a view in which technology causes a shift in the demand for different types of labor but the supply curve is stable and the observed changes in wages and employment are simply movements along this supply curve ${ }^{11}$.

In a competitive labor market it is wages in different segments that determine the position on the supply curve, so to reconcile the observed increase in relative employment in the worst jobs together with a fall in their relative wages one would have to try to explain how a fall in wages at the bottom end of the labor market increases labor supply in that part of the labor market. While this might not be impossible (the labor supply curve could conceivably be backward-bending) it does not seem especially plausible. It is perhaps more plausible to think that the labor supply curve is not stable and the labor force has changed in a way that has increased the number of workers who typically do lousy jobs. It should be fairly obvious that the shifts in the educational attainment of the workforce should be such as to decrease the supply of workers who typically do bad jobs. But, perhaps the change in the

\footnotetext{
${ }^{11}$ The Appendix presents a simple three-skill competitive model of the labor market that can be used as a more formal justification for the discussion that follows. Juhn [1994] presents a model in which she claims that a fall in the demand for 'middling' jobs reduces wages more at the bottom but hers is really only a model with 2 types of skill but 'middling' people with some combination of both skills. In this example there is no well-defined sense of a fall in demand for middling jobs.
} 
gender and age composition of the workforce has some explanatory power ${ }^{12}$. The next section explores this possibility.

\section{Can Supply Changes explain Relative Wage Changes?}

The top panel of Figure IX shows that, as is well-known, women tend to be over-represented in bad jobs. This raises the possibility that the increased labor force participation of women has depressed wages in those occupations.

To formally assess the importance of increased female participation and the changing age composition of the labor force we construct a counterfactual allowing for changes in the number of men and women in the labor force and the age composition while keeping the occupational composition for a given age-gender combination constant over time. The estimates for the relationship between the actual employment change and the initial median wage reported in the first 2 columns of Table XI are the same as those reported in Table IIa. The final 2 columns of Table XI report the point estimates of a regression of counterfactual employment growth onto job median wages and its square in 1979. Though the coefficients do have the appropriate signs to predict the J-shape and are mostly significant, a comparison shows that the supply changes can only explain a small part of the change in wage dispersion. This should come as no surprise given the fact we argued before that there has been an increase in the number of good and bad jobs for males as well as females. And these estimates almost certainly over-state the importance of supply shocks as women are entering different (and better) jobs than they used to as shown by the bottom panel of Figure IX.

\footnotetext{
12 One might also think that immigration is another potentially important supply shock. But the fraction foreign-born in the UK labor force only rose from $7.3 \%$ in 1979 to $8.9 \%$ in 1989 and this rise was concentrated in the later years. These changes are too small to have a large impact.
} 
This still leaves us with the puzzle as to why wages have been falling in lousy jobs relative to those in 'middling' jobs. One possible way to do this is to think of the labor market as being non-competitive in some way. There are a number of ways in which this could be done.

For example, Acemoglu (2001) presents a model of a labor market with frictions in which an increase in the supply of skilled workers encourages employers to create more lovely and lousy jobs and fewer middling jobs. In this type of model 'supply creates its own demand' and there is no need to resort to demand shocks caused by technological change to explain job polarization. But it is a little bit hard to see how supply shocks of this type can explain the pattern of changes in occupational employment seen in Tables IV-VI - technology seems much more plausible as an explanation for these changes. But, the Acemoglu story may have some relevance for explaining what is happening within occupations when employers often have a decision about what level of skill to require of workers doing these jobs.

Another 'non-competitive' explanation is that institutions have changed in such a way as to lead to a fall in wages at the bottom end of the wage distribution. There is now a small literature in the US (DiNardo at al. [1996], Lee [1999], Teulings [2000]) that suggests that the evolution of unionization and the minimum wage can do a very good job in explaining what is happening to the bottom half of the wage distribution. The UK has also seen a marked decline in unionization, a decline in minimum wages (though they were never very strong) and the indexation of welfare benefits to prices not wages. Perhaps these changes can account for the rise in wage inequality in the bottom half of the distribution in the 1980s. We leave the further exploration of this to another paper. 


\section{Conclusions}

There is little doubt that technology has a powerful impact on the labor market. But, the dominant current view about the nature of its impact, the hypothesis of skillbiased technical change is only a partial truth and cannot explain all of the important changes in the labor market (see Card and DiNardo [2002] for an additional list of puzzles and problems). Crudely, the SBTC hypothesis seems best able to explain what is happening in the top half of the wage distribution but not its bottom half. There, the more nuanced view about the impact of technology proposed by Autor, Levy and Murnane [2003] seems appropriate and it seems plausible that demand for 'middling' jobs has fallen. This paper has provided UK evidence of increased job polarization that is consistent with the ALM hypothesis. It would be interesting to know whether similar phenomena can be observed in the Continental European countries that have not had the rises in wage inequality seen in the UK and the US. 


\section{References}

Acemoglu, Daron "Changes in Unemployment and Wage Inequality: An Alternative Theory and Some Evidence", American Economic Review, 89 (1999), 1259-1278.

Acemoglu, Daron, "Good Jobs versus Bad Jobs", Journal of Labor Economics, XIX (2001), 1-21.

Autor, David H, Frank Levy and Richard J Murnane, "The Skill Content of Recent Technological Change: An Empirical Exploration," Quarterly Journal of Economics, CXVIII (2003), 1279-1333.

Baumol, William J., "Macroeconomics of Unbalanced Growth: the Anatomy of Urban Crisis," American Economic Review, LVII (1967), 415-426.

Berman, Eli, John Bound and Zvi Griliches, "Changes in the Demand for Skilled Labor within U.S. Manufacturing: Evidence from the Annual Survey of Manufactures," Quarterly Journal of Economics, CIX (1994), 367-97.

Berman, Eli, John Bound and Stephen Machin, "Implications of Skill-Biased Technological Change: International Evidence,” Quarterly Journal of Economics, CXII (1998), 1245-79.

Bluestone, Barry and Bennet Harrison (1988), "The Growth of Low-Wage Employment: 1963-1986,” American Economic Review, LXXVIII (1988), 124-128.

Burtless, Gary, A Future of Lousy Jobs?: The Changing Structure of US Wages, Brookings Institution Press.

Card, David and John DiNardo, "Skill-Biased Technological Change and Rising Wage Inequality: Some Problems and Puzzles," Journal of Labor Economics, XX (2002), 733-783.

Card, David and Thomas Lemieux, "Wage Dispersion, Returns to Skill, and Black-White Wage Differentials," Journal of Econometrics, LXXIV (1996), 319-61.

Chevalier, Arnaud, "Graduate Over-education in the UK," Centre for the Economics of Education Discussion Paper No. 7, 2000, LSE.

Costrell, Robert M., "Methodology in the "Job Quality" Debate," Industrial Relations, XXIX (1990), 94-110.

DiNardo, John., Nicole Fortin and Thomas Lemieux, "Labor Market Institutions and the distribution of wages, 1973-1992," Econometrica, LXIV (1996), 1001-1044. 
Dunne, Timothy, Lucia Foster, John Haltiwanger and Kenneth Troske, "Wage and Productivity Dispersion in US Manufacturing: The Role of Computer Investment," NBER Working Paper 7465, 2000.

Farber, Henry S., "Job Creation in the United States: Good Jobs or Bad?", Princeton Industrial Relations Section Working Paper, No. 385, July 1997.

Felstead, Alan, Duncan Gallie and Francis Green, "Work Skills in Britain, 19862001," Department for Education and Skills, 2002.

Gittleman, Maury B. and David R. Howell, "Changes in the Structure and Quality of Jobs in the United States: Effects by Race and Gender, 1973-1990," Industrial and Labor Relations Review, XLVIII (1995), 420-440.

Green, Francis, Steven McIntosh and Anna Vignoles, "Overeducation and Skills Clarifying the Concepts," LSE CEP DP No. 435, 1999.

Green, Francis and Steven McIntosh, "Is there a Genuine Underutilisation of Skills Amongs the Over-Qualified," LSE CEP Working Paper, 2002.

Hartog, J., "On returns to Education: Wandering Among the Hills of ORU Land,"in Heijke, Hans and Muysken, Joan, eds. Education and training in a knowledgebased economy. London: Macmillan, 2000.

Hellerstein, Judith K, David Neumark and Kenneth R. Troske, "Wages, Productivity and Worker Characteristics: Evidence from Plant-Level Production Functions and Wage Equations", Journal of Labor Economics, VII (1999), 409-446.

Howell, David R. and Edward N. Wolff, "Trends in the Growth and Distribution of Skills in the U.S. Workplace, 1960-1985," Industrial and Labor Relations Review, XLIV(1991), 486-502.

Ilg, Randy E., “The nature of employment growth, 1989-1995,” Monthly Labor Review, CXIX (1996), 29-36.

Ilg, Randy E. and StevenE. Haugen, "Earnings and Employment Trends in the 1990s," Monthly Labor Review, March 2000, 21-33.

Juhn, Chinhui, "Wage Inequality and Industrial Change: Evidence from Five Decades," NBER Working Paper No. 4684, 1994.

Juhn, Chinhui, "Wage Inequality and Demand for Skill: Evidence from Five Decades," Industrial and Labor Relations Review, LII (1999), 424-443.

Juhn, Chinhui, Murphy Kevin M. and Brooks Pierce, "Wage Inequality and the Rise in Returns to Skill," Journal of Policital Economy, CI (1993), 410-442.

Katz, Lawrence F. and David H. Autor, "Changes in the Wage Structure and Earnings Inequality," in Ashenfelter, Orley and David Card (eds) Handbook of Labor Economics. Volume 3A. Amsterdam: North-Holland, 1999, 1463-1555. 
Kosters, Marvin H. and Murray N. Ross, “A Shrinking Middle Class?,” Public Interest, 1988, 3-27.

Lee, David S., "Wage Inequality in the United States During the 1980s: Rising Dispersion or Falling Minimum Wage?," Quarterly Journal of Economics, CXIV (1999), 941-1023.

Lemieux, Thomas, "Decomposing Wage Distributions: a Unified Approach" Canadian Journal of Economics, 35 (4), November 2002, 646-88.

Levy, Frank and Richard J. Murnane, "U.S. Earnings Levels and Earnings Inequality: A Review of Recent Trends and Proposed Explanation", Journal of Economic Literature, 30:3, September 1992, 1333-1381.

Machin, Stephen, "Labor Market Inequality and Changes in the Relative Demand for Skills", mimeograph LSE, 2002.

Machin, Stephen and John van Reenen, "Technology and Changes in Skill Structure: Evidence from Seven OECD Countries," Quarterly-Journal-of-Economics, CXIII (1998), 1215-44.

Meisenheimer, Joseph R. II, "The services industry in the 'good' versus 'bad' jobs debate," Monthly Labor Review, February 1998, 22-47.

Murphy, Kevin M and Finis Welch (1993) "Occupational Change and the Demand for Skill, 1940-1990”, American Economic Review, LXXXIII (1993), 122-36.

OECD, "The Characteristics and Quality of Service Sector Jobs," OECD Employment Outlook, 2001, 89-128.

Sicherman, Nachum (1991) "Overeducation in the Labor Market", Journal of Labor Economics, IX (1991), 101-122.

Spenner, Kenneth I., "Deciphering Prometheus: temporal change in the skill level of work," American Sociological Review, XLVIII (1983), 824-37.

Spitz, Alexandra, "IT Capital, Job Content and Educational Attainment," Centre for European Economic Research Discussion Paper No. 03-04, 2003.

Teulings, Coen, N., "Aggregation Bias in Elasticities of Substitution and the Minimum Wage Paradox,” International Economic Review, XLI (2000), 359-98.

Wright, Erik Olin and Rachel Dwyer, "The Patterns of Job Expansions in the United States: a comparison of the 1960s and 1990s," forthcoming Socio-Economic Review (2003), I. 
Table I

DOT Task Density by Wage Percentiles

\begin{tabular}{|l|c|c|c|c|}
\hline \multirow{2}{*}{ DOT Task Measure } & $\begin{array}{c}\text { Mean DOT Task } \\
\text { Measure }\end{array}$ & \multicolumn{3}{|c|}{$\begin{array}{c}\text { Fraction of workers above mean DOT } \\
\text { task measure by wage percentiles }\end{array}$} \\
\cline { 3 - 5 } & & $\leq 33$ & $33-66$ & $\geq 66$ \\
\hline Non-Routine Cognitive & 3.755 & 0.17 & 0.48 & 0.88 \\
\hline Non-Routine Interactive & 2.417 & 0.03 & 0.14 & 0.59 \\
\hline Routine Cognitive & 4.582 & 0.37 & 0.63 & 0.43 \\
\hline Routine Manual & 3.901 & 0.28 & 0.58 & 0.35 \\
\hline Non-Routine Manual & 1.198 & 0.49 & 0.33 & 0.31 \\
\hline
\end{tabular}

Notes: Task inputs are measured as in ALM [2003] and are between 0 and 10. The mean DOT task measure is the 1977 mean across 3-digit occupations. Wage percentiles are taken from the CPS MORG 1983 file. 
Table IIa

The Relationship between Employment Growth and Initial Median Wage:

Men and Women Together

\begin{tabular}{|c|c|c|c|c|c|c|}
\hline Sample & $\begin{array}{c}\text { Sample } \\
\text { Period }\end{array}$ & Data & $\begin{array}{c}\text { Employment } \\
\text { Measure }\end{array}$ & $\beta 1$ & $\beta 2$ & $\begin{array}{c}\text { Fraction } \\
\text { in } \\
\text { Declining } \\
\text { Section }\end{array}$ \\
\hline Men+Women & $1979-99$ & $\begin{array}{c}\text { LFS } \\
\text { (occ) }\end{array}$ & Employment & $\begin{array}{c}-4.541 \\
(0.700)\end{array}$ & $\begin{array}{c}2.107 \\
(0.297)\end{array}$ & 52.93 \\
\hline Men+Women & $1976-95$ & $\begin{array}{c}\text { NES } \\
\text { (occ) }\end{array}$ & Employment & $\begin{array}{c}-3.412 \\
(0.664)\end{array}$ & $\begin{array}{c}1.373 \\
(0.267)\end{array}$ & 72.57 \\
\hline Men+Women & $1979-99$ & $\begin{array}{c}\text { LFS } \\
\text { (occXind) }\end{array}$ & Employment & $\begin{array}{c}-4.804 \\
(0.472)\end{array}$ & $\begin{array}{c}2.109 \\
(0.198)\end{array}$ & 62.80 \\
\hline Men+Women & $1976-95$ & $\begin{array}{c}\text { NES } \\
\text { (occXind) }\end{array}$ & Employment & $\begin{array}{c}-3.957 \\
(0.378)\end{array}$ & $\begin{array}{c}1.581 \\
(0.151)\end{array}$ & 74.69 \\
\hline Men+Women & $1979-99$ & $\begin{array}{c}\text { LFS } \\
\text { (occ) }\end{array}$ & Hours & $\begin{array}{c}-4.218 \\
(0.785)\end{array}$ & $\begin{array}{c}2.047 \\
(0.327)\end{array}$ & 28.42 \\
\hline Men+Women & $1976-95$ & $\begin{array}{c}\text { NES } \\
\text { (occ) }\end{array}$ & Hours & $\begin{array}{c}-3.603 \\
(0.775)\end{array}$ & $\begin{array}{c}1.576 \\
(0.319)\end{array}$ & 56.85 \\
\hline Men+Women & $1979-99$ & $\begin{array}{c}\text { LFS } \\
\text { (occXind) }\end{array}$ & Hours & $\begin{array}{c}-4.331 \\
(0.514)\end{array}$ & $\begin{array}{c}1.969 \\
(0.213)\end{array}$ & 49.67 \\
\hline & $1976-95$ & $\begin{array}{c}\text { NES } \\
\text { (occXind) }\end{array}$ & Hours & $\begin{array}{c}-4.145 \\
(0.435)\end{array}$ & $\begin{array}{c}1.748 \\
(0.178)\end{array}$ & 62.22 \\
\hline
\end{tabular}

Notes: Regressions are weighted by job cell size in the initial period. Occupation uses 3-digit SOC90 codes. Industry uses 1-digit SIC80 codes. 
Table IIb

The Relationship Between Employment Growth and Initial Median Wage:

Men

\begin{tabular}{|c|c|c|c|c|c|c|}
\hline Sample & $\begin{array}{c}\text { Sample } \\
\text { Period }\end{array}$ & Data & $\begin{array}{c}\text { Employment } \\
\text { Measure }\end{array}$ & $\beta 1$ & $\beta 2$ & $\begin{array}{c}\text { Fraction } \\
\text { in } \\
\text { Declining } \\
\text { Section }\end{array}$ \\
\hline Men & $1979-99$ & $\begin{array}{c}\text { LFS } \\
\text { (occ) }\end{array}$ & Employment & $\begin{array}{c}-5.807 \\
(1.317)\end{array}$ & $\begin{array}{c}2.447 \\
(0.482)\end{array}$ & 39.66 \\
\hline Men & $1976-95$ & $\begin{array}{c}\text { NES } \\
\text { (occ) }\end{array}$ & Employment & $\begin{array}{c}-3.080 \\
(1.097)\end{array}$ & $\begin{array}{c}1.267 \\
(0.389)\end{array}$ & 43.33 \\
\hline Men & $1979-99$ & $\begin{array}{c}\text { LFS } \\
\text { (occXind) }\end{array}$ & Employment & $\begin{array}{c}-6.039 \\
(0.719)\end{array}$ & $\begin{array}{c}2.413 \\
(0.265)\end{array}$ & 55.84 \\
\hline Men & $1976-95$ & $\begin{array}{c}\text { NES } \\
\text { (occXind) }\end{array}$ & Employment & $\begin{array}{c}-4.697 \\
(0.535)\end{array}$ & $\begin{array}{c}1.783 \\
(0.191)\end{array}$ & 68.91 \\
\hline Men & $1979-99$ & $\begin{array}{c}\text { LFS } \\
\text { (occ) }\end{array}$ & Hours & $\begin{array}{c}-5.022 \\
(1.361)\end{array}$ & $\begin{array}{c}2.246 \\
(0.502)\end{array}$ & 27.98 \\
\hline Men & $1976-95$ & $\begin{array}{c}\text { NES } \\
\text { (occ) }\end{array}$ & Hours & $\begin{array}{c}-4.732 \\
(1.266)\end{array}$ & $\begin{array}{c}1.981 \\
(0.463)\end{array}$ & 39.10 \\
\hline Men & $1979-99$ & $\begin{array}{c}\text { LFS } \\
\text { (occXind) }\end{array}$ & Hours & $\begin{array}{c}-5.622 \\
(0.755)\end{array}$ & $\begin{array}{c}2.337 \\
(0.281)\end{array}$ & 45.48 \\
\hline & $\begin{array}{c}\text { NES } \\
\text { (occXind) }\end{array}$ & Hours & $\begin{array}{c}-5.906 \\
(0.618)\end{array}$ & $\begin{array}{c}2.309 \\
(0.226)\end{array}$ & 64.32 \\
\hline
\end{tabular}

Notes: Regressions are weighted by job cell size in the initial period. Occupation uses 3-digit SOC90 codes. Industry uses 1-digit SIC80 codes. 
Table IIc

The Relationship between Employment Growth and Initial Median Wage:

Women

\begin{tabular}{|c|c|c|c|c|c|c|}
\hline Sample & $\begin{array}{c}\text { Sample } \\
\text { Period }\end{array}$ & Data & $\begin{array}{c}\text { Employment } \\
\text { Measure }\end{array}$ & $\beta 1$ & $\beta 2$ & $\begin{array}{c}\text { Fraction } \\
\text { in } \\
\text { Declining } \\
\text { Section }\end{array}$ \\
\hline Women & $1979-99$ & $\begin{array}{c}\text { LFS } \\
\text { (occ) }\end{array}$ & Employment & $\begin{array}{c}-1.580 \\
(1.025)\end{array}$ & $\begin{array}{c}1.222 \\
(0.505)\end{array}$ & - \\
\hline Women & $1976-95$ & $\begin{array}{c}\text { NES } \\
\text { (occ) }\end{array}$ & Employment & $\begin{array}{c}-0.657 \\
(0.686)\end{array}$ & $\begin{array}{c}0.584 \\
(0.310)\end{array}$ & - \\
\hline Women & $1979-99$ & $\begin{array}{c}\text { LFS } \\
\text { (occXind) }\end{array}$ & Employment & $\begin{array}{c}-3.363 \\
(0.840)\end{array}$ & $\begin{array}{c}1.942 \\
(0.411)\end{array}$ & 54.69 \\
\hline Women & $1976-95$ & $\begin{array}{c}\text { NES } \\
\text { (occXind) }\end{array}$ & Employment & $\begin{array}{c}-2.227 \\
(0.517)\end{array}$ & $\begin{array}{c}1.256 \\
(0.239)\end{array}$ & 50.95 \\
\hline Women & $1979-99$ & $\begin{array}{c}\text { LFS } \\
\text { (occ) }\end{array}$ & Hours & $\begin{array}{c}-1.441 \\
(1.177)\end{array}$ & $\begin{array}{c}1.415 \\
(0.597)\end{array}$ & - \\
\hline Women & $1976-95$ & $\begin{array}{c}\text { NES } \\
\text { (occ) }\end{array}$ & Hours & $\begin{array}{c}-0.776 \\
(0.815)\end{array}$ & $\begin{array}{c}0.887 \\
(0.401)\end{array}$ & - \\
\hline Women & $1979-99$ & $\begin{array}{c}\text { LFS } \\
\text { (occXind) }\end{array}$ & Hours & $\begin{array}{c}-3.199 \\
(0.934)\end{array}$ & $\begin{array}{c}2.034 \\
(0.466)\end{array}$ & 34.17 \\
\hline
\end{tabular}

Notes: Regressions are weighted by job cell size in the initial period. Occupation uses 3-digit SOC90 codes. Industry uses 1-digit SIC80 codes. 
Table III

The Relationship between Employment Growth and Terminal Median Wage

\begin{tabular}{|c|c|c|c|c|c|c|}
\hline Sample & $\begin{array}{c}\text { Sample } \\
\text { Period }\end{array}$ & Data & $\begin{array}{c}\text { Employment } \\
\text { Measure }\end{array}$ & $\beta 1$ & $\beta 2$ & $\begin{array}{c}\text { Fraction } \\
\text { in } \\
\text { Declining } \\
\text { Section }\end{array}$ \\
\hline Men+Women & $1979-99$ & $\begin{array}{c}\text { LFS } \\
\text { (occ) }\end{array}$ & Employment & $\begin{array}{c}-1.915 \\
(0.491)\end{array}$ & $\begin{array}{c}0.839 \\
(0.166)\end{array}$ & 29.59 \\
\hline Men+Women & $1976-95$ & $\begin{array}{c}\text { NES } \\
\text { (occ) }\end{array}$ & Employment & $\begin{array}{c}-2.920 \\
(0.387)\end{array}$ & $\begin{array}{c}1.090 \\
(0.127)\end{array}$ & 54.96 \\
\hline Men+Women & $1979-99$ & $\begin{array}{c}\text { LFS } \\
\text { (occXind) }\end{array}$ & Employment & $\begin{array}{c}-0.581 \\
(0.289)\end{array}$ & $\begin{array}{c}0.403 \\
(0.097)\end{array}$ & - \\
\hline Men+Women & $1976-95$ & $\begin{array}{c}\text { NES } \\
\text { (occXind) }\end{array}$ & Employment & $\begin{array}{c}-2.416 \\
(0.231)\end{array}$ & $\begin{array}{c}0.915 \\
(0.076)\end{array}$ & 50.36 \\
\hline Men+Women & $1979-99$ & $\begin{array}{c}\text { LFS } \\
\text { (occ) }\end{array}$ & Hours & $\begin{array}{c}-1.651 \\
(0.519)\end{array}$ & $\begin{array}{c}0.806 \\
(0.171)\end{array}$ & 17.22 \\
\hline Men+Women & $1976-95$ & $\begin{array}{c}\text { NES } \\
\text { (occ) }\end{array}$ & Hours & $\begin{array}{c}-2.770 \\
(0.433)\end{array}$ & $\begin{array}{c}1.101 \\
(0.140)\end{array}$ & 38.97 \\
\hline Men+Women & $1979-99$ & $\begin{array}{c}\text { LFS } \\
\text { (occXind) }\end{array}$ & Hours & $\begin{array}{c}-0.271 \\
(0.286)\end{array}$ & $\begin{array}{c}0.356 \\
(0.094)\end{array}$ & - \\
\hline & $1976-95$ & $\begin{array}{c}\text { NES } \\
\text { (occXind) }\end{array}$ & Hours & $\begin{array}{c}-2.506 \\
(0.264)\end{array}$ & $\begin{array}{c}1.003 \\
(0.085)\end{array}$ & 37.21 \\
\hline
\end{tabular}

Notes: Regressions are weighted by job cell size in the terminal period. Occupation uses 3-digit SOC90 codes. Industry uses 1-digit SIC80 codes. 
Table IV

Top 10 Occupations by Job Growth

\begin{tabular}{|c|c|c|c|c|}
\hline Occupation & $\begin{array}{c}\text { Median } \\
\text { wage in } \\
1979\end{array}$ & $\begin{array}{l}\text { Employment } \\
\quad \text { in } 1979\end{array}$ & $\begin{array}{l}\text { Employment } \\
\quad \text { in } 1999\end{array}$ & $\begin{array}{c}\text { \% change } \\
\text { in } \\
\text { employment }\end{array}$ \\
\hline All & 3.052 & 24332613 & 27343467 & 12.373 \\
\hline Care assistants \& attendants & 2.345 & 103837 & 539407 & 419.474 \\
\hline Software engineers & 5.008 & 34009 & 171769 & 405.065 \\
\hline $\begin{array}{l}\text { Management consultants \& } \\
\text { business analysts }\end{array}$ & 4.745 & 18811 & 81803 & 334.868 \\
\hline $\begin{array}{l}\text { Computer systems \& data } \\
\text { processing managers }\end{array}$ & 5.065 & 43239 & 178701 & 313.286 \\
\hline $\begin{array}{l}\text { Computer analysts \& } \\
\text { programmers }\end{array}$ & 4.842 & 76083 & 302617 & 297.745 \\
\hline Educational assistants & 2.272 & 45040 & 173763 & 285.793 \\
\hline Hospital ward assistants & 2.572 & 7460 & 26986 & 261.705 \\
\hline $\begin{array}{l}\text { Actors, entertainers, stage } \\
\text { managers \& producers }\end{array}$ & 4.719 & 22549 & 73030 & 223.870 \\
\hline $\begin{array}{l}\text { Treasurers \& company } \\
\text { financial managers }\end{array}$ & 5.105 & 37794 & 119812 & 217.015 \\
\hline $\begin{array}{l}\text { Financial institution and } \\
\text { office managers }\end{array}$ & 4.511 & 107138 & 322608 & 201.114 \\
\hline
\end{tabular}

Notes: Employment data are taken from the LFS using 3-digit SOC90 codes. Wages are 1979 median hourly wages taken from the NES using 3-digit SOC90 codes. 
Table V

Bottom 10 Occupations by Median Wage

\begin{tabular}{|c|c|c|c|c|}
\hline Occupation & $\begin{array}{c}\text { Median } \\
\text { wage in } \\
1979\end{array}$ & $\begin{array}{l}\text { Employment } \\
\text { in } 1979\end{array}$ & $\begin{array}{l}\text { Employment } \\
\text { in } 1999\end{array}$ & $\begin{array}{c}\text { \% change } \\
\text { in } \\
\text { employment }\end{array}$ \\
\hline All & 3.052 & 24332613 & 27343467 & 12.373 \\
\hline Hairdresser \& barbers & 1.745 & 123986 & 96073 & -22.513 \\
\hline Bar staff & 1.832 & 119455 & 188319 & 57.647 \\
\hline Shelf fillers & 1.938 & 49699 & 97144 & 95.462 \\
\hline Sales assistants & 1.939 & 954200 & 1321251 & 38.466 \\
\hline $\begin{array}{l}\text { Retail cash desk \& check-out } \\
\text { operators }\end{array}$ & 1.969 & 112816 & 218581 & 93.749 \\
\hline $\begin{array}{l}\text { Petrol pump forecourt } \\
\text { attendants }\end{array}$ & 1.979 & 13304 & 9935 & -25.321 \\
\hline Kitchen porters & 2.003 & 178758 & 143092 & -19.952 \\
\hline Waiters \& waitresses & 2.020 & 124780 & 187391 & 50.177 \\
\hline Cleaners & 2.132 & 854535 & 649362 & -24.009 \\
\hline Beauticians & 2.145 & 24536 & 28946 & 17.972 \\
\hline
\end{tabular}

Notes: Employment data are taken from the LFS using 3-digit SOC90 codes. Wages are 1979 median hourly wages taken from the NES using 3-digit SOC90 codes. 
Table VI

Bottom 10 Occupations by Job Growth

\begin{tabular}{|c|c|c|c|c|}
\hline Occupation & $\begin{array}{l}\text { Median } \\
\text { wage in } \\
1979\end{array}$ & $\begin{array}{l}\text { Employment } \\
\text { in } 1979\end{array}$ & $\begin{array}{l}\text { Employment } \\
\text { in } 1999\end{array}$ & $\begin{array}{l}\text { \% change } \\
\text { in } \\
\text { employment }\end{array}$ \\
\hline All & 3.052 & 24332613 & 27343467 & 12.373 \\
\hline $\begin{array}{l}\text { Boring \& drilling machine } \\
\text { setters \& setter-operators }\end{array}$ & 3.584 & 29276 & 1731 & -94.086 \\
\hline Coal mine laborers & 3.696 & 29782 & 1818 & -93.892 \\
\hline $\begin{array}{l}\text { Face trained coalmining } \\
\text { workers, shotfirers \& deputies }\end{array}$ & 5.237 & 76301 & 5095 & -93.322 \\
\hline $\begin{array}{l}\text { Ginding machine setters \& } \\
\text { operators }\end{array}$ & 3.557 & 56426 & 8164 & -85.531 \\
\hline Laborers in foundries & 3.219 & 14801 & 2505 & -83.070 \\
\hline $\begin{array}{l}\text { Laborers in engineering \& } \\
\text { allied trades }\end{array}$ & 3.025 & 58243 & 12758 & -78.095 \\
\hline $\begin{array}{l}\text { Electrical, energy, boiler \& } \\
\text { related plant operatives \& } \\
\text { attendants }\end{array}$ & 3.684 & 36352 & 8009 & -77.968 \\
\hline $\begin{array}{l}\text { Spinners, doublers \& twisters } \\
\text { (in textiles and tannery } \\
\text { process operatives) }\end{array}$ & 2.802 & 16941 & 4173 & -75.363 \\
\hline $\begin{array}{l}\text { Originators, compositors \& } \\
\text { print preparers (in printing } \\
\text { and related trades) }\end{array}$ & 3.404 & 48878 & 12162 & -75.116 \\
\hline $\begin{array}{l}\text { Rail signal operatives \& } \\
\text { crossing keepers }\end{array}$ & 3.010 & 13761 & 3571 & -74.045 \\
\hline
\end{tabular}

Notes: Employment data are taken from the LFS using 3-digit SOC90 codes. Wages are 1979 median hourly wages taken from the NES using 3-digit SOC90 codes. 
Table VII

Shift-share Analysis of Employment Shares by Occupation

\begin{tabular}{|c|c|c|c|c|c|c|c|}
\hline Occupation & Wage & & $N E S$ & & & $L F S$ & \\
\hline & & total & within & between & total & within & between \\
\hline $\begin{array}{l}\text { Professional occupations } \\
\qquad(N M)\end{array}$ & 5.914 & 1.709 & 1.127 & 0.582 & 3.733 & 2.838 & 0.895 \\
\hline $\begin{array}{l}\text { Managers and } \\
\text { administrators }\end{array}$ & 4.117 & 5.204 & 4.588 & 0.616 & 5.606 & 5.271 & 0.335 \\
\hline $\begin{array}{l}\text { Associate professional and } \\
\text { technical occupations }(N M)\end{array}$ & 3.823 & 2.579 & 1.700 & 0.879 & 4.466 & 3.446 & 1.020 \\
\hline $\begin{array}{l}\text { Craft and related } \\
\text { occupations }\end{array}$ & 3.277 & -8.158 & -3.738 & -4.420 & -7.883 & -3.461 & -4.422 \\
\hline $\begin{array}{l}\text { Plant and machine } \\
\text { operatives }\end{array}$ & 3.055 & -5.579 & -1.809 & -3.770 & -5.195 & -1.362 & -3.833 \\
\hline $\begin{array}{l}\text { Clerical and secretarial } \\
\text { occupations }\end{array}$ & 2.841 & 1.291 & -1.879 & 3.171 & -2.105 & -5.388 & 3.283 \\
\hline $\begin{array}{l}\text { Personal and protective } \\
\text { service occupation }(N M / M)\end{array}$ & 2.668 & 3.516 & 1.969 & 1.547 & 3.502 & 1.732 & 1.770 \\
\hline $\begin{array}{l}\text { Other occupations } \\
\end{array}$ & 2.558 & -2.527 & -2.775 & 0.248 & -3.398 & -3.564 & 0.166 \\
\hline Sales occupations & 2.132 & 1.964 & 0.817 & 1.147 & 1.272 & 0.487 & 0.785 \\
\hline
\end{tabular}

Notes: Employment changes are taken between 1979 and 1999 for the LFS and 1976-1995 for the NES. Reported wages are 1979 median hourly wages taken from the NES using 1-digit SOC90 occupations. The decomposition is done using 1-digit SIC80 industry codes. 
Table VIII

DOT Task Shifts Within and Between Occupations

\begin{tabular}{|c|c|c|c|c|}
\hline DOT Task Measure & Mean 1977 & \multicolumn{3}{|c|}{ Change 1977-1991 } \\
\hline \multicolumn{5}{|c|}{ Panel A: Good and Bad Occupations } \\
\hline & & total & within & between \\
\hline Non-Routine Cognitive & 3.755 & 0.084 & -0.047 & 0.131 \\
\hline Non-Routine Interactive & 2.417 & 0.504 & 0.137 & 0.367 \\
\hline Routine Cognitive & 4.582 & -0.854 & -0.564 & -0.290 \\
\hline Routine Manual & 3.901 & -0.146 & -0.025 & -0.121 \\
\hline Non-Routine Manual & 1.198 & -0.132 & -0.094 & -0.038 \\
\hline \multicolumn{5}{|c|}{ Panel B: Bad Occupations } \\
\hline Non-Routine Cognitive & 3.338 & -0.027 & -0.106 & 0.079 \\
\hline Non-Routine Interactive & 2.169 & 0.367 & 0.019 & 0.348 \\
\hline Routine Cognitive & 3.929 & -1.116 & -0.871 & -0.245 \\
\hline Routine Manual & 3.879 & -0.224 & -0.065 & -0.159 \\
\hline Non-Routine Manual & 0.847 & -0.037 & -0.032 & -0.005 \\
\hline
\end{tabular}

Notes: Task inputs are measured as in ALM [2003] and are between 0 and 10. For Panel A, the reported means are weighted using 463 3-digit COC occupations. Panel B uses 208 occupations with hourly earnings below overall average wages using 1984 CPS data. Changes between 1977 and 1991 are measured using 3-digit COC occupations and employment changes between 1984 and 1997. 
Table IX

Changes in Skill Requirements within Jobs, 1986-2001

\begin{tabular}{|c|c|c|}
\hline Occupation & $\begin{array}{c}\text { Change in education level } \\
\text { required to get job, } \\
\text { 1986-2001 }\end{array}$ & $\begin{array}{c}\text { Change in fraction } \\
\text { reporting required } \\
\text { education not necessary to } \\
\text { do job, 1986-2001 }\end{array}$ \\
\hline Managerial & 0.25 & 0.014 \\
\hline Professional & 0.12 & 0.021 \\
\hline $\begin{array}{c}\text { Associate } \\
\text { Professional }\end{array}$ & 0.31 & 0.072 \\
\hline Clerical & 0.10 & 0.046 \\
\hline Craft & 0.25 & 0.110 \\
\hline Personal Services & 0.50 & 0.093 \\
\hline Sales & 0.54 & 0.063 \\
\hline Operatives & 0.08 & 0.076 \\
\hline Elementary & 0.24 & \\
\hline
\end{tabular}

Notes: Data come from 1986 SCELI data and 2001 Skills Survey. Education required is measured on a 5-point scale with 1 being no qualifications and 5 a college degree. 
Table X

Relationship between Wage Growth and Initial Median Wage

\begin{tabular}{|c|c|c|c|c|}
\hline Sample & $\begin{array}{c}\text { Sample } \\
\text { Period }\end{array}$ & Data & $\begin{array}{c}\text { Relative to } \\
1976\end{array}$ & $\begin{array}{c}\text { Relative to } \\
1977\end{array}$ \\
\hline Men+Women & $1976-95$ & $\begin{array}{c}\text { NES } \\
\text { (occ) }\end{array}$ & $\begin{array}{c}0.239 \\
(0.029)\end{array}$ & $\begin{array}{c}0.267 \\
(0.029)\end{array}$ \\
\hline Men+Women & $1976-95$ & $\begin{array}{c}\text { NES } \\
\text { (occXind) }\end{array}$ & $\begin{array}{c}0.109 \\
(0.013)\end{array}$ & $\begin{array}{c}0.156 \\
(0.014)\end{array}$ \\
\hline Men & $1976-95$ & $\begin{array}{c}\text { NES } \\
\text { (occ) }\end{array}$ & $\begin{array}{c}0.374 \\
(0.033)\end{array}$ & $\begin{array}{c}0.403 \\
(0.033)\end{array}$ \\
\hline Men & $1976-95$ & $\begin{array}{c}\text { NES } \\
\text { (occXind) }\end{array}$ & $\begin{array}{c}0.178 \\
(0.017)\end{array}$ & $\begin{array}{c}0.237 \\
(0.017)\end{array}$ \\
\hline Women & $1976-95$ & $\begin{array}{c}\text { NES } \\
\text { (occ) }\end{array}$ & $\begin{array}{c}0.284 \\
(0.052)\end{array}$ & $\begin{array}{c}0.371 \\
(0.052)\end{array}$ \\
& & NES & 0.086 & 0.188 \\
& & & $(0.027)$ & $(0.029)$ \\
\hline Women & $1976-95$ & (occXind) & & \\
& & & & \\
& & & & \\
\hline
\end{tabular}

Notes: Regressions are weighted by initial job cell size in terms of employment. The dependent variable is the change in log wages between 1976 and 1995, the regressors the log wage in 1976 or 1977. 
Table XI

The Impact of Supply Changes

\begin{tabular}{|c|c|c|c|c|c|c|}
\hline \multirow{2}{*}{$\begin{array}{l}\text { Sample } \\
\text { Period }\end{array}$} & \multirow[t]{2}{*}{ Data } & \multirow{2}{*}{$\begin{array}{c}\text { Employment } \\
\text { Measure }\end{array}$} & \multicolumn{2}{|c|}{ Actual } & \multicolumn{2}{|c|}{ Counterfactual } \\
\hline & & & $\beta 1$ & $\beta 2$ & $\beta 1$ & $\beta 2$ \\
\hline $1979-99$ & $\begin{array}{l}\text { LFS } \\
\text { (occ) }\end{array}$ & Employment & $\begin{array}{l}-4.541 \\
(0.700)\end{array}$ & $\begin{array}{c}2.107 \\
(0.297)\end{array}$ & $\begin{array}{l}-1.022 \\
(0.100)\end{array}$ & $\begin{array}{c}0.378 \\
(0.042)\end{array}$ \\
\hline $1976-95$ & $\begin{array}{l}\text { NES } \\
\text { (occ) }\end{array}$ & Employment & $\begin{array}{l}-3.412 \\
(0.664)\end{array}$ & $\begin{array}{c}1.373 \\
(0.267)\end{array}$ & $\begin{array}{l}-0.908 \\
(0.121)\end{array}$ & $\begin{array}{c}0.312 \\
(0.048)\end{array}$ \\
\hline $1979-99$ & $\begin{array}{c}\text { LFS } \\
\text { (occXind) }\end{array}$ & Employment & $\begin{array}{l}-4.804 \\
(0.472)\end{array}$ & $\begin{array}{c}2.109 \\
(0.198)\end{array}$ & $\begin{array}{l}-0.834 \\
(0.041)\end{array}$ & $\begin{array}{c}0.300 \\
(0.017)\end{array}$ \\
\hline $1976-95$ & $\begin{array}{c}\text { NES } \\
\text { (occXind) }\end{array}$ & Employment & $\begin{array}{l}-3.957 \\
(0.378)\end{array}$ & $\begin{array}{c}1.581 \\
(0.151)\end{array}$ & $\begin{array}{l}-0.717 \\
(0.041)\end{array}$ & $\begin{array}{c}0.241 \\
(0.016)\end{array}$ \\
\hline 1979-99 & $\begin{array}{l}\text { LFS } \\
\text { (occ) }\end{array}$ & Hours & $\begin{array}{l}-4.218 \\
(0.785)\end{array}$ & $\begin{array}{c}2.047 \\
(0.327)\end{array}$ & $\begin{array}{l}-0.842 \\
(0.120)\end{array}$ & $\begin{array}{c}0.325 \\
(0.049)\end{array}$ \\
\hline $1976-95$ & $\begin{array}{l}\text { NES } \\
\text { (occ) }\end{array}$ & Hours & $\begin{array}{l}-3.603 \\
(0.775)\end{array}$ & $\begin{array}{c}1.576 \\
(0.319)\end{array}$ & $\begin{array}{l}-0.688 \\
(0.129)\end{array}$ & $\begin{array}{c}0.253 \\
(0.053)\end{array}$ \\
\hline 1979-99 & $\begin{array}{c}\text { LFS } \\
\text { (occXind) }\end{array}$ & Hours & $\begin{array}{l}-4.331 \\
(0.514)\end{array}$ & $\begin{array}{c}1.969 \\
(0.213)\end{array}$ & $\begin{array}{l}-0.603 \\
(0.048)\end{array}$ & $\begin{array}{c}0.229 \\
(0.020)\end{array}$ \\
\hline $1976-95$ & $\begin{array}{c}\text { NES } \\
\text { (occXind) }\end{array}$ & Hours & $\begin{array}{l}-4.145 \\
(0.435)\end{array}$ & $\begin{array}{c}1.748 \\
(0.178)\end{array}$ & $\begin{array}{l}-0.506 \\
(0.044)\end{array}$ & $\begin{array}{c}0.186 \\
(0.018)\end{array}$ \\
\hline
\end{tabular}

Notes: Regressions are weighted by job cell size in the initial period. Occupation uses 3 digit SOC90 codes. Industry uses 1 digit SIC80 codes. The counterfactual allows for changes in the number of men and women in the labor force and the age composition (using 5-year age brackets) while keeping constant the occupational composition for a given age-gender combination. 
Figure I

Percentage Change in Employment Share by Job Quality Decile

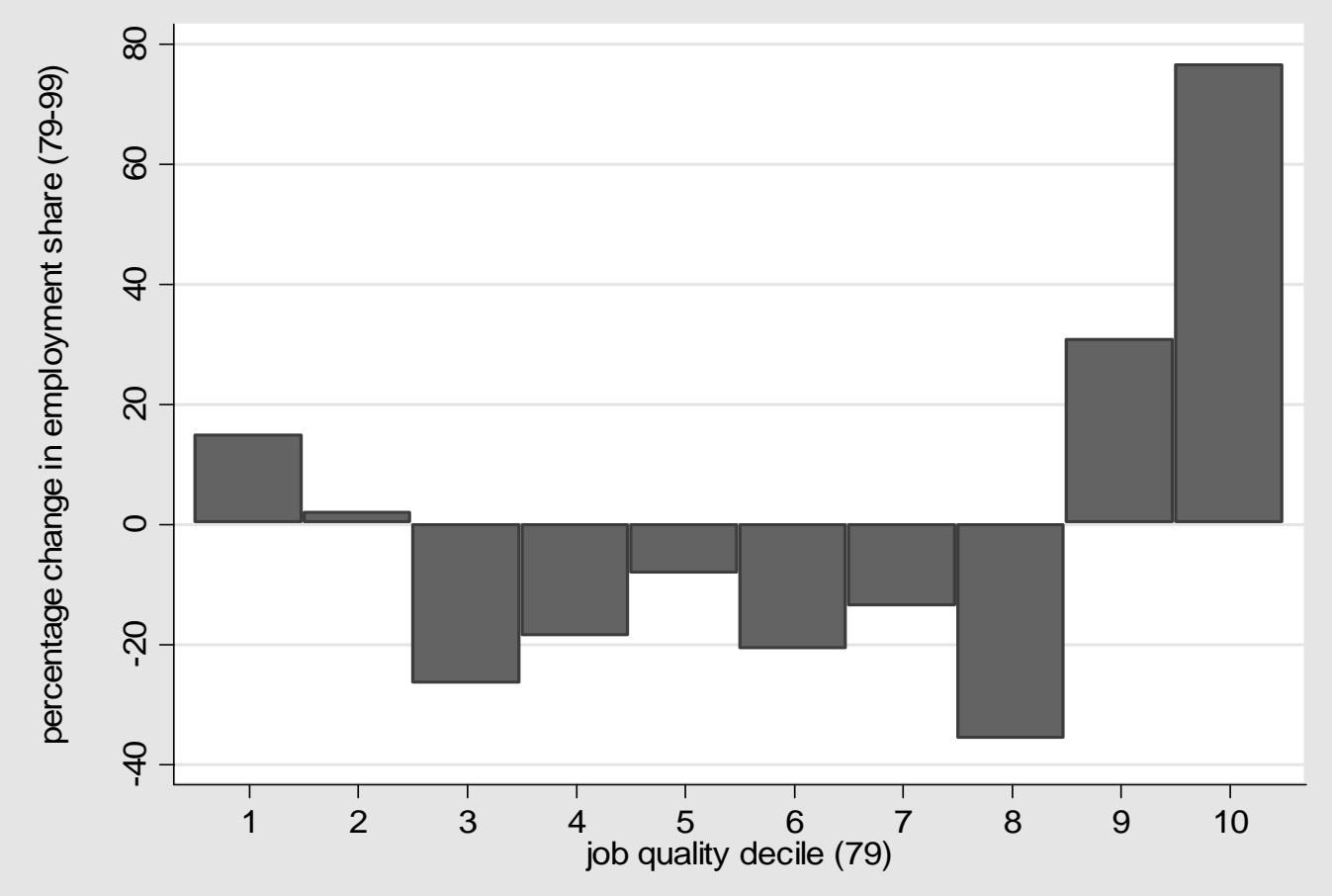

Notes: Employment data are taken from the LFS using 3-digit SOC90 codes.

Employment changes are taken between 1979 and 1999. Quality deciles are based on 3-digit SOC90 median wages in 1979 taken from the NES. 
Figure II

Employment Growth by Job Median Wage

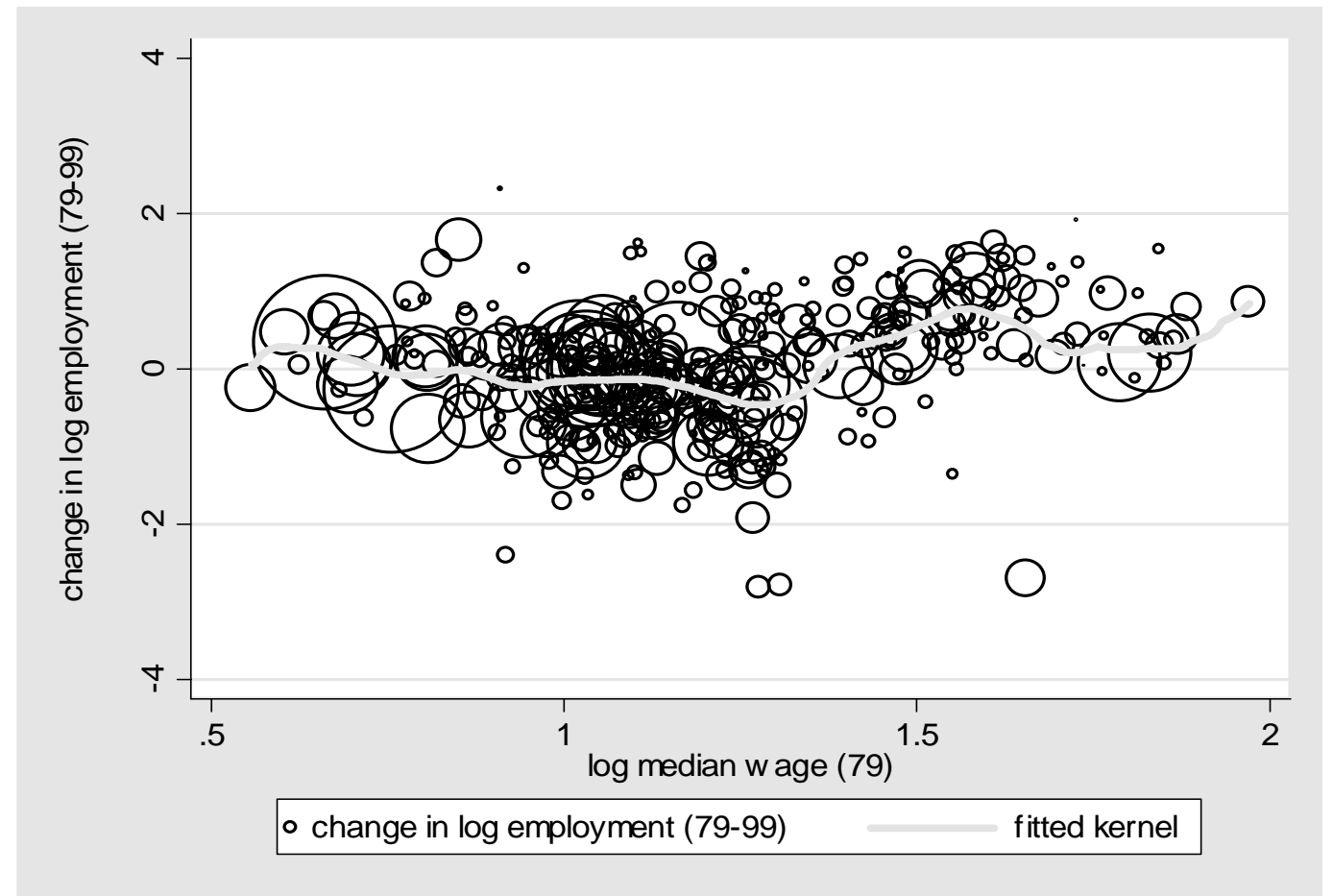

Notes: Employment data are taken from the LFS using 3-digit SOC90 codes. Employment changes are taken between 1979 and 1999. Wages are 3-digit SOC90 median wages in 1979 taken from the NES. 
Figure III

The Impact of Job Polarization on Employment Growth by Wage Percentile

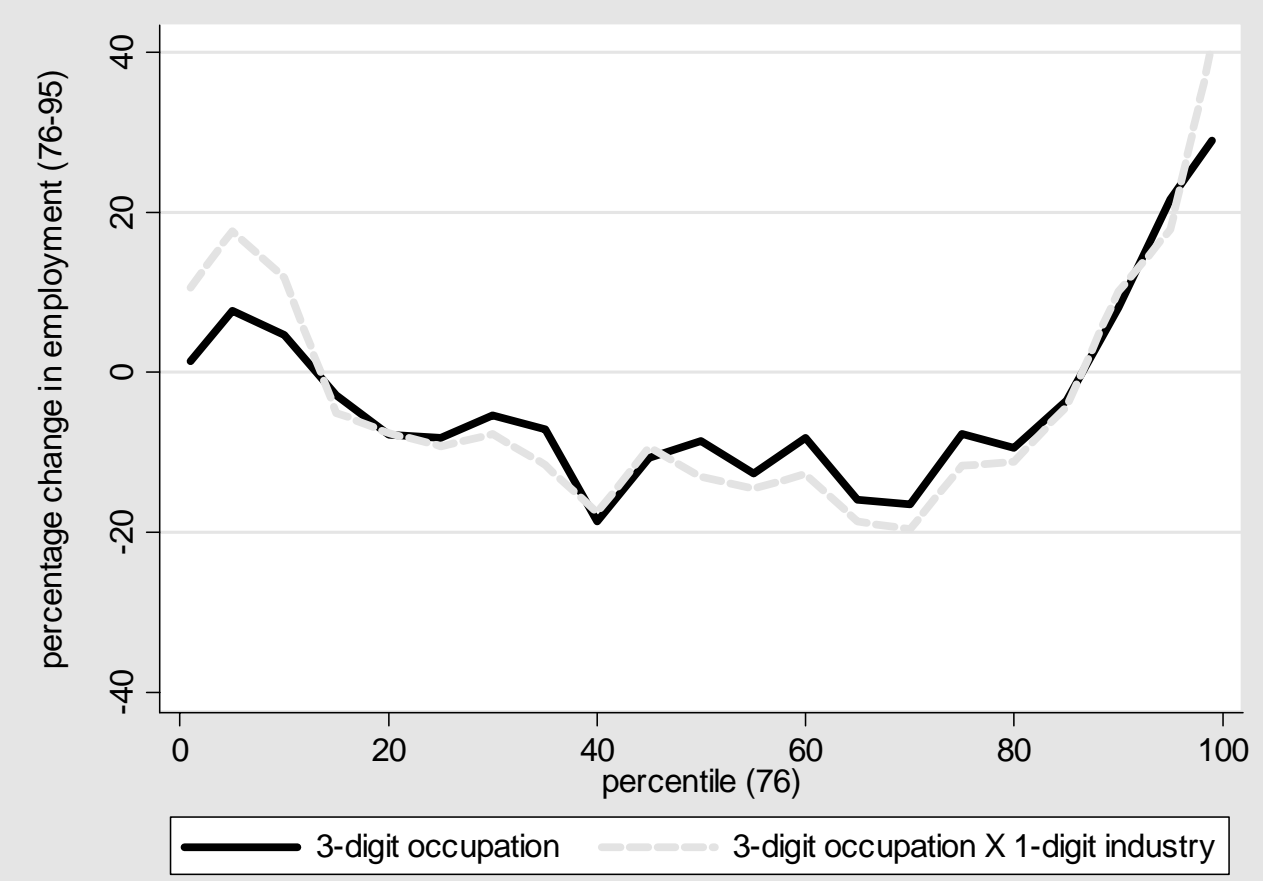

Notes: Data are taken from the NES using 3-digit SOC90 codes. Employment changes are taken between 1976 and 1995. Percentiles are the 1976 wage density percentiles. 
Figure IV

How Much of Rising Educational Attainment can be explained by Job Polarization?

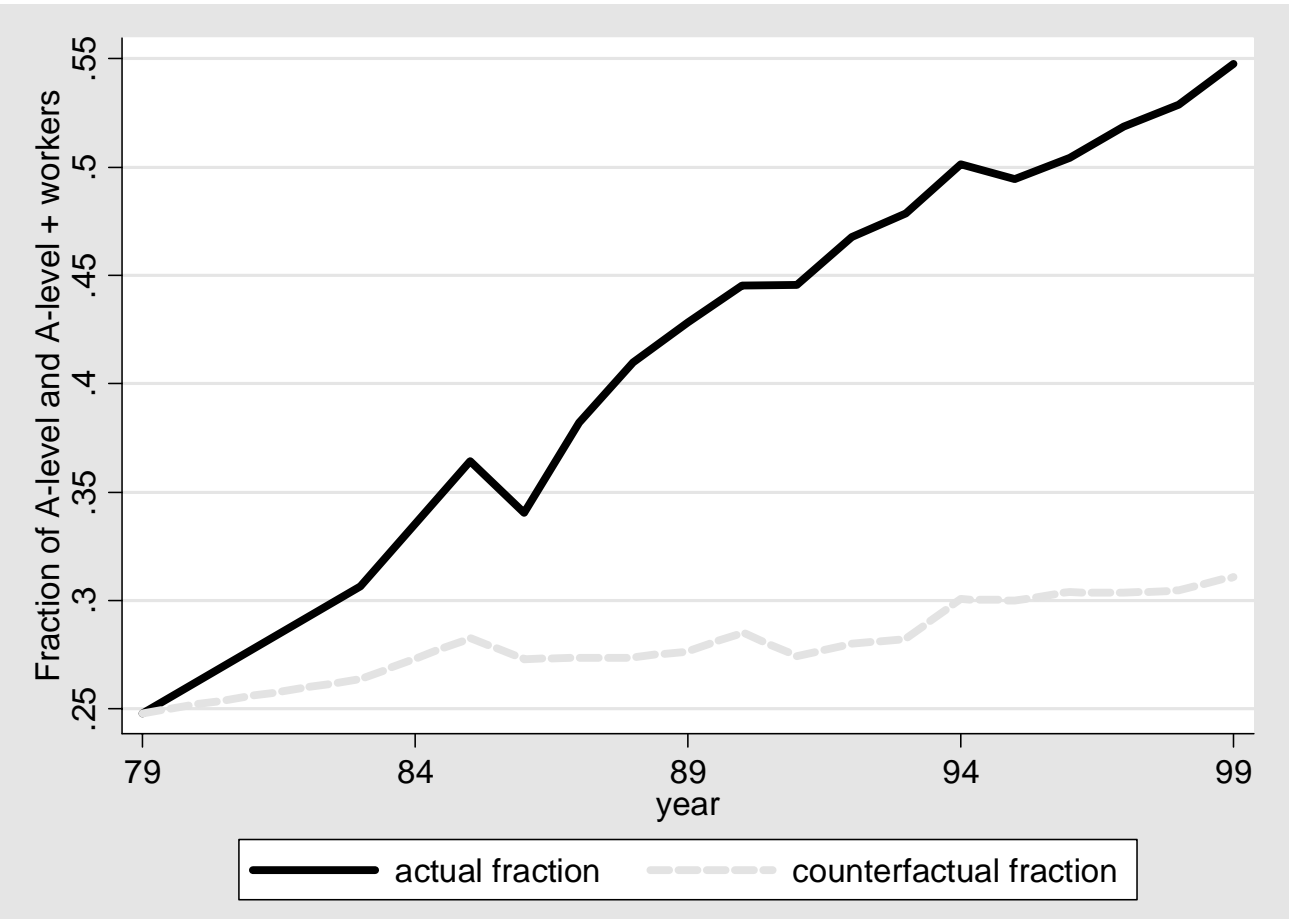

Notes: Data are taken from the LFS using 3-digit SOC90 occupation codes. 
Figure V

Fraction and Change in Fraction of Workers by Education and Job Median Wage
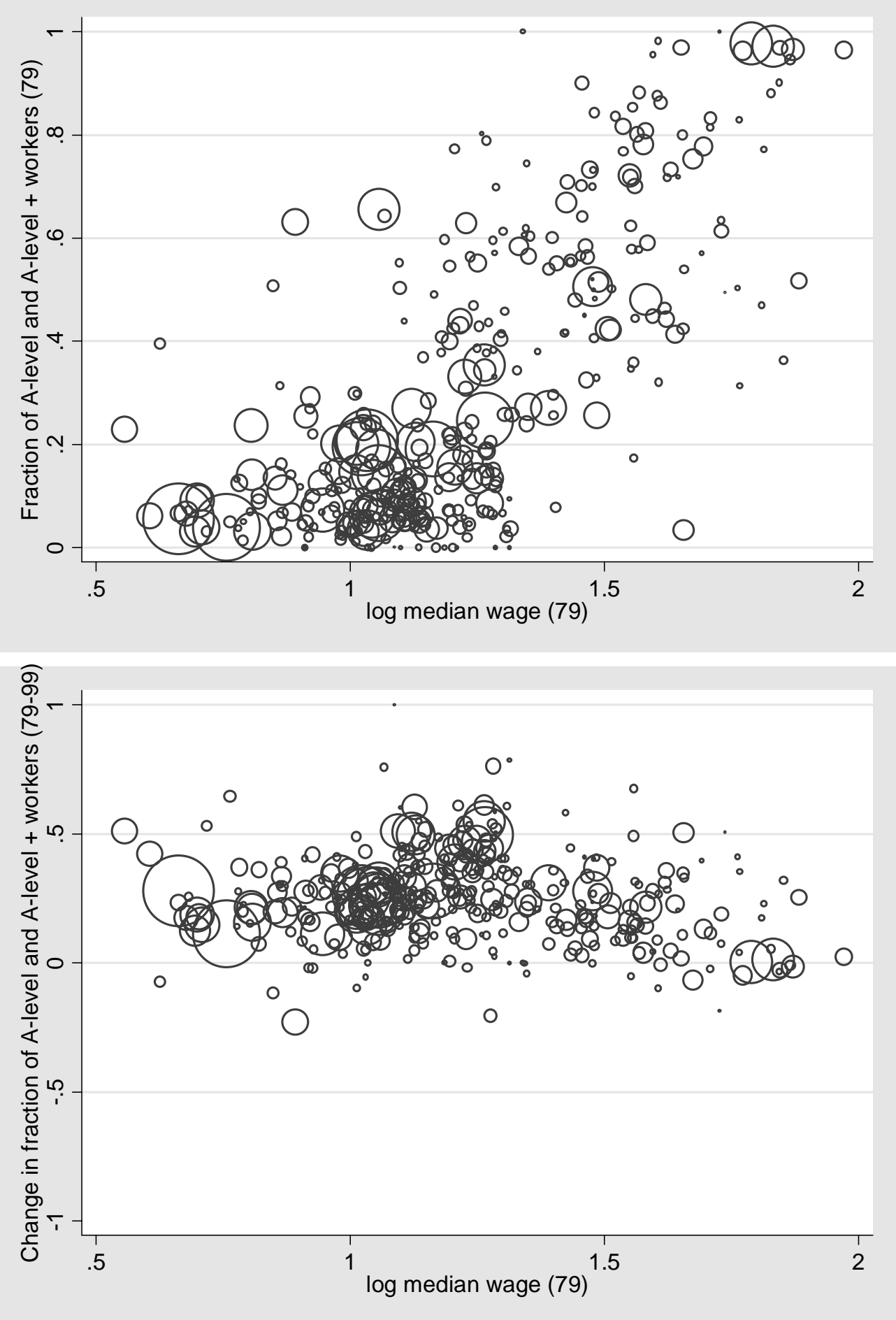

Notes: Employment data are taken from the LFS using 3-digit SOC90 codes. 
Figure VI

How Much of Actual Wage Dispersion Can Be Explained by Job Polarization?
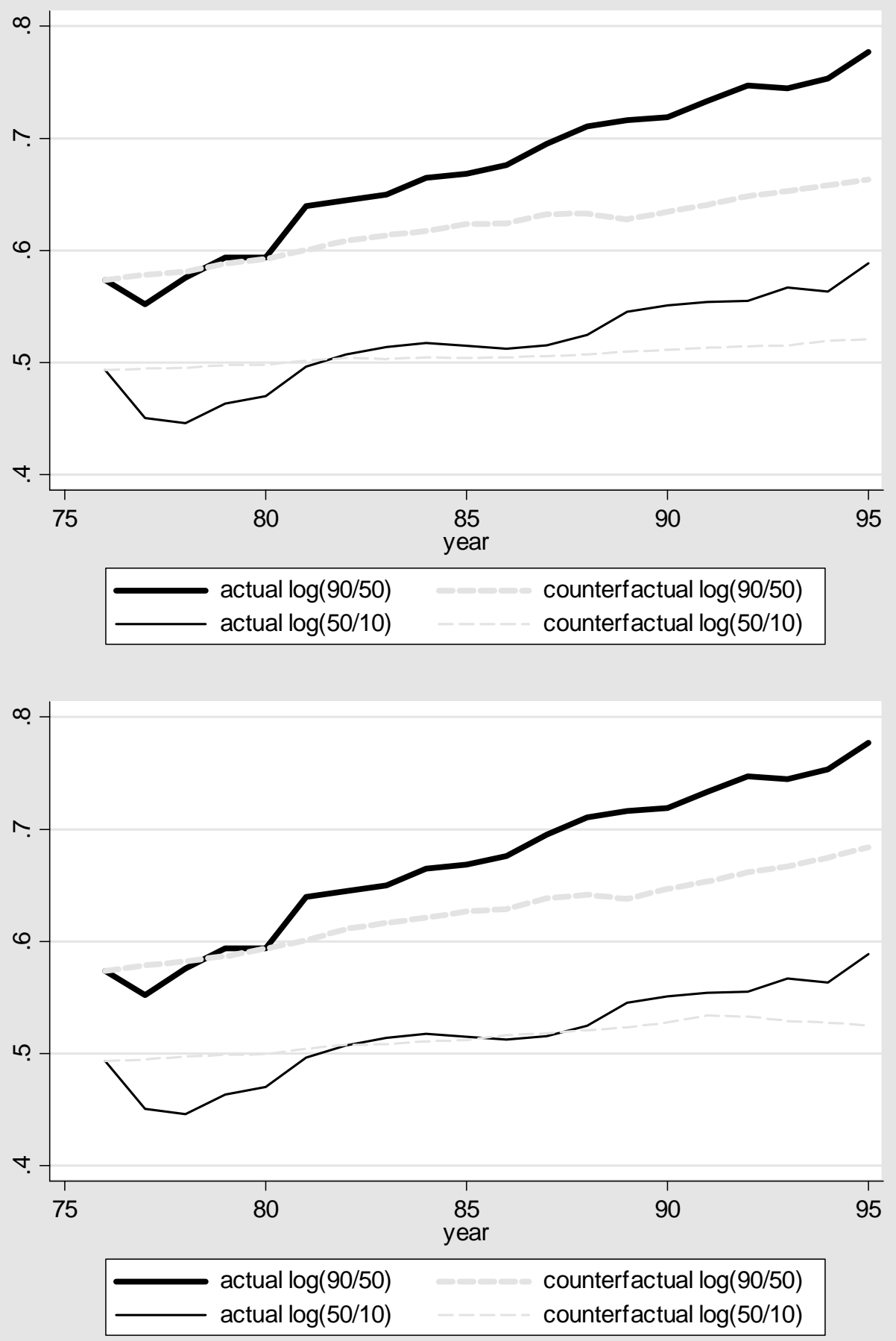

Notes: Data are taken from the NES. The top panel uses 3-digit SOC90 codes. The bottom panel uses 3-digit SOC90 codes interacted with 1-digit SIC80 codes. The counterfactual keeps constant median wage and wage dispersion within occupations. 


\section{Figure VII}

The Impact of Job Polarization and Changing Relative Wages Across Jobs on Wage Inequality
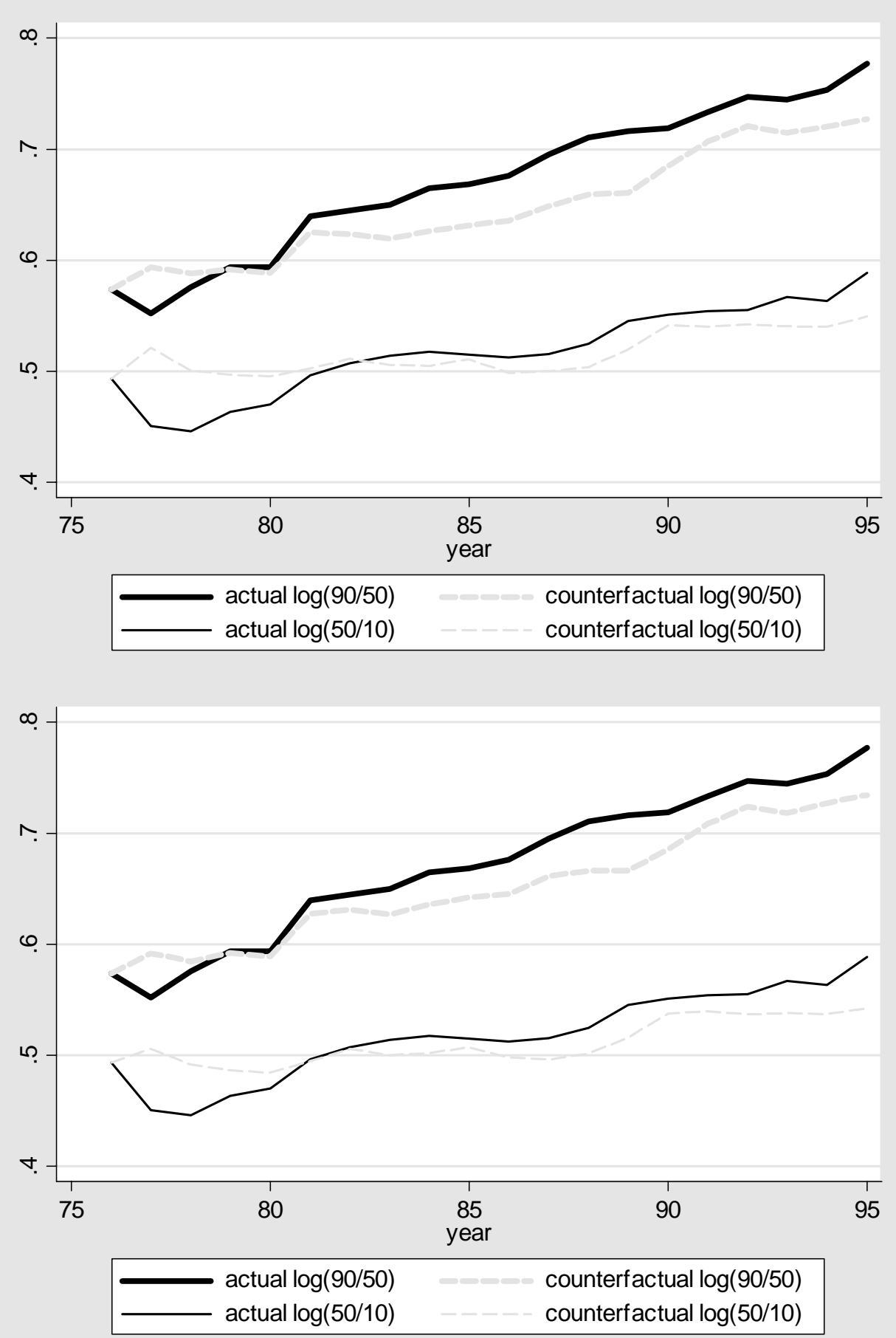

Notes: Data are taken from the NES. The top panel uses 3-digit SOC90 codes. The bottom panel uses 3-digit SOC90 codes interacted with 1-digit SIC80 codes. The counterfactual keeps constant wage dispersion within occupations. 


\section{Figure VIII \\ The Changing $\mathbf{R}^{2}$ in the UK Earnings Function}

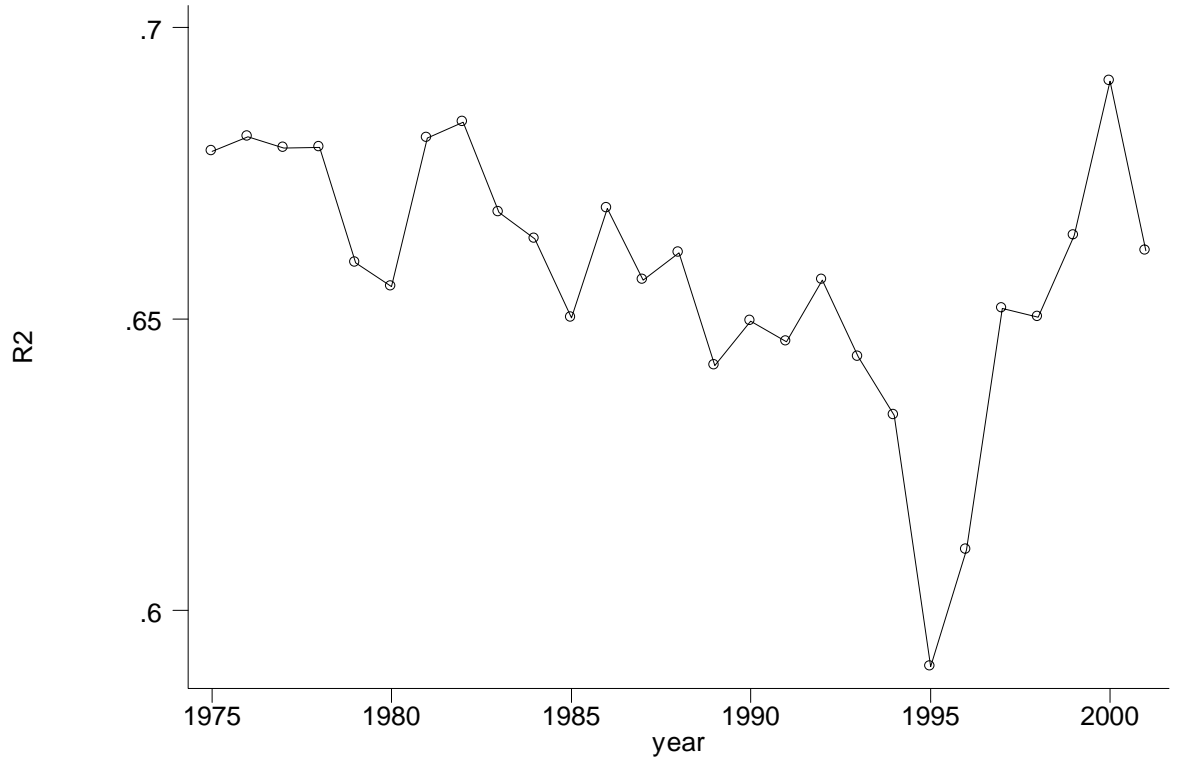

Notes: Data are taken from the NES. The dependent variable is log hourly earnings and the covariates included are age, industry and occupation dummies, all interacted with gender. The dip in 1995 and 1996 is the result of considerably more workers reporting implausibly low wages of below $£ 0.5$ per hour. If the data is trimmed the dip is much less pronounced. 
Figure IX

Fraction and Change in the Fraction of Female Workers by Job Median Wage
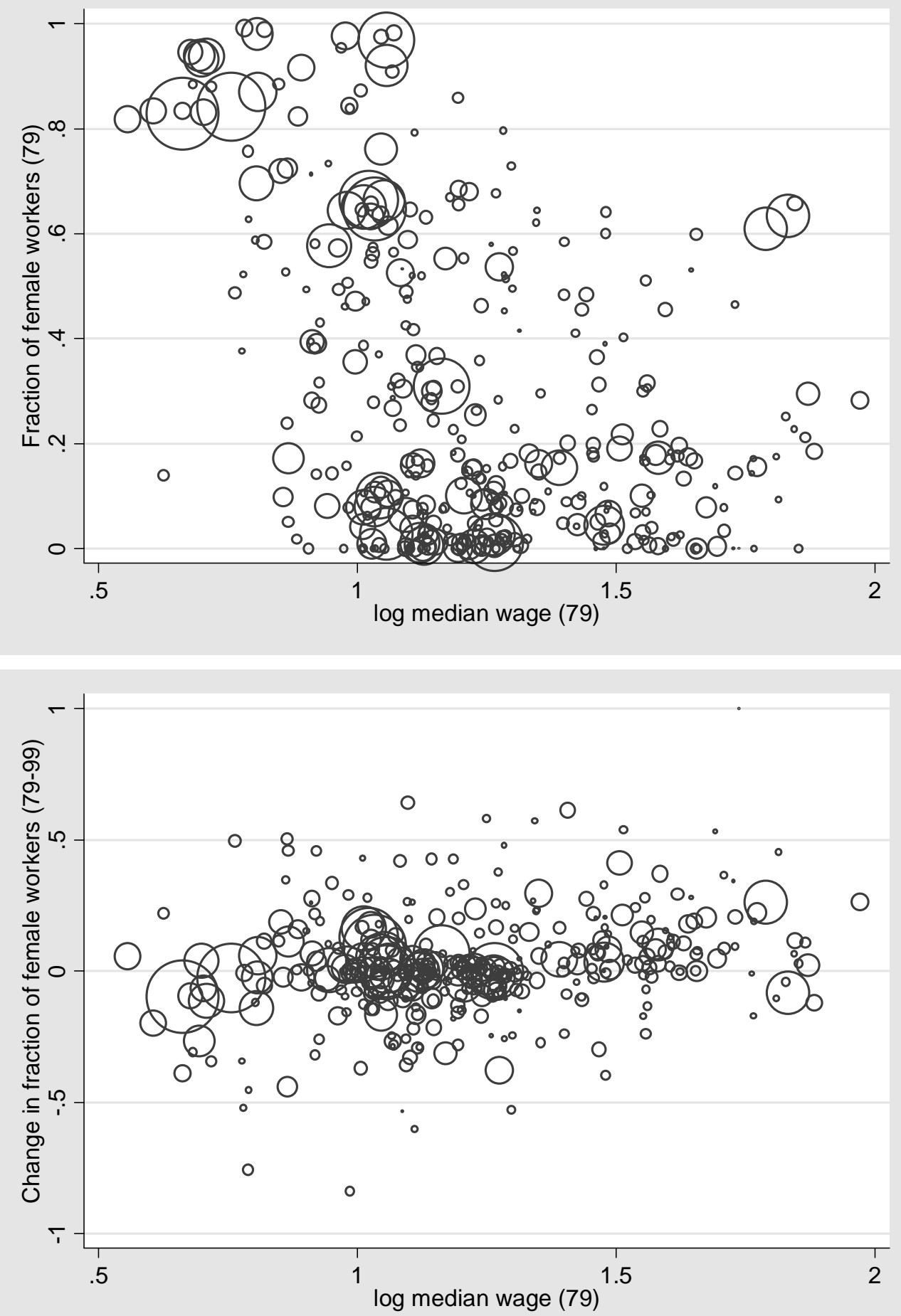

Notes: Employment data are taken from the LFS using 3-digit SOC90 codes. 


\section{Appendix \\ The Response of Relative Wages and Employment to a Demand Shock}

Let us assume there are three different kinds of labor that we shall call low, medium and high-skill. Denote the share in employment of the three types by $N_{L}, N_{M}, N_{H}$ and their wages by $W_{L}, W_{M}, W_{H}$. We are going to be interested in how relative wages and employment change with particular types of technical progress. As a 'numeraire' let us choose the middle skill level and define:

$$
x_{i}=X_{i} / X_{M}, \quad i=L, H, \quad X=N, W
$$

and similar notation will be used later for other variables that are introduced.

We are interested in whether a simple supply and demand model with a labour demand shock (caused by changes in technology) can explain the stylised facts of rising job polarization with faster employment growth at the top and rising wage inequality. In terms of the model what has happened in the data is $d \ln \left(N_{H}\right)>d \ln \left(N_{L}\right)>0$, (the job polarization) and $d \ln \left(w_{L}\right)<0<d \ln \left(w_{H}\right)$ (rising wage inequality) and the question is whether we can find a plausible technology shock and parameter values to make this the outcome of a simple supply and demand model. We start with the problematic part which is the supply curve and then turn to the unproblematic part, the demand curve.

\section{The Labour Supply Curve}

We will take a simple model in which aggregate labor supply is fixed and individuals need to decide whether to work in low-skill, middling or high-skill jobs. In this case the supply of labour to a particular skill level will potentially depend on the wages of all three skill groups but will be homogeneous of degree zero in these wages. The most natural assumption is that the supply of labour to a particular segment is increasing in its own wage and decreasing in the wage of the other segments. But, if this is the case we cannot interpret the observed job polarization and rising wage inequality as a move along a stable supply curve caused by a technology-induced shift in the demand for labour as the fall in the wage of low-skill workers relative to both high-skill and middling workers should induce a fall in the supply of labour to the low-skill segment.

To see this more formally consider a simple model. Assume that the utility of individual i from working in a job of skill $\mathrm{s}$ is given by:

$$
U_{i s}=\frac{W_{i}}{C_{i s}}
$$

where the ' $\mathrm{C}$ ' represents a difficulty for individual $\mathrm{i}$ of working in a particular job: we will assume there is heterogeneity in these parameters across individuals.

Individuals choose to supply labor to the segment that offers the highest utility. It is more common to assume that skill levels for individuals are immutable but this set-up allows relative wages to affect supplies of labor to different segments. One can always model the fact that certain workers cannot work in high-skill jobs by assuming that $C_{H}$ is very high for them.

The decision for individual i will be the following: work in the low-skill segment if: 


$$
c_{i L}=\frac{C_{i L}}{C_{i M}}<\frac{W_{L}}{W_{M}}=w_{L}, \quad c_{i L}<c_{i H} \frac{W_{L}}{W_{H}}=c_{i H} \frac{w_{L}}{w_{H}}
$$

work in the middle segment if:

$$
c_{i L}>w_{L}, \quad c_{i H}>\frac{W_{H}}{W_{M}}=w_{H}
$$

and work in the high-skill segment if:

$$
c_{i H}<w_{H}, \quad c_{i L}>c_{i H} \frac{w_{L}}{w_{H}}
$$

Note that the decision of each individual only depends on relative wages so aggregate labor supplies only depend on relative wages. One can represent the decision of each individual for given relative wages on a simple diagram - Figure A1.

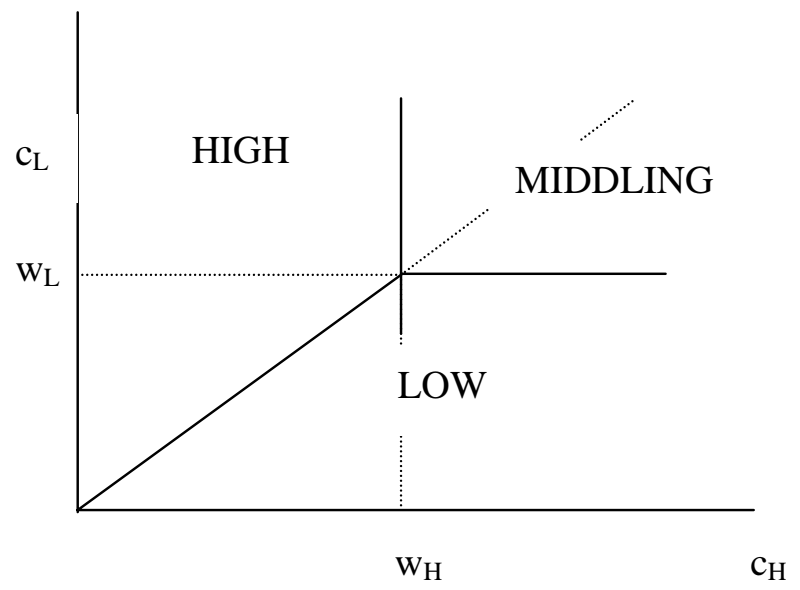

The overall labor supplies will be determined by the distribution of individuals' relative skill costs. We know from the technology that we need to have both more skilled and unskilled workers relative to middling ones associated with rising wage inequality. The rise in wage inequality will alter the picture in the following way:

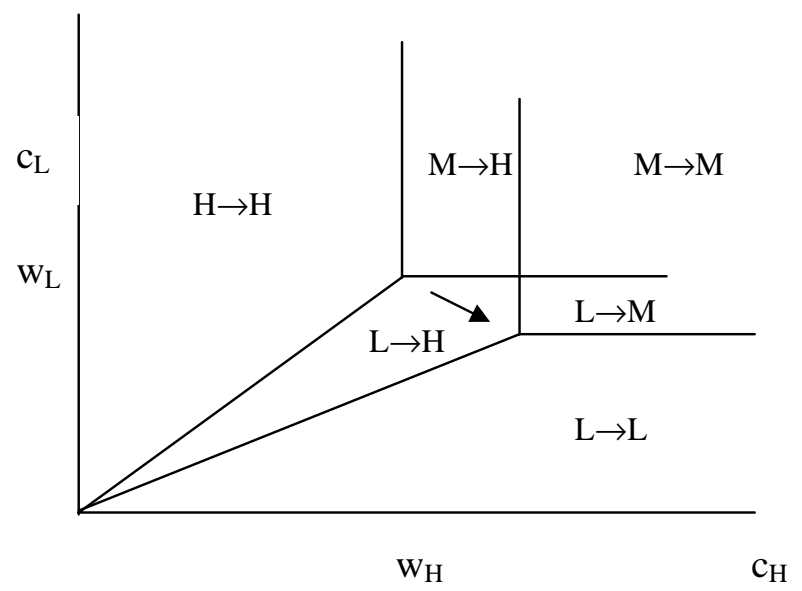


Where we have marked the initial skill decision and the final one associated with each region. One can see that there is an unambiguous increase in the supply of labor to the high-skill segment and a fall in supply to the low-skill segment. The important point is that this type of model cannot explain the simultaneous of observation of falling relative wages in low-skill jobs together with a rise in the share of employment ${ }^{13}$.

So, if a simple demand-supply framework is to explain what is going on, we need to have a supply curve in which falling wages at the bottom lead to an increase in labor supply there i.e. the labor supply curve has a 'backward-bending' aspect, the plausibility of which is open to question.

\section{The Labour Demand Curve}

It is not difficult to present a production function in which technological change induces, for fixed relative wages, job polarization. For example, suppose that the production function has the following Leontief form:

$$
Y=\min \left(A_{L} N_{L}, A_{M} N_{M}, A_{H} N_{H}\right)
$$

Then, using the fact that $N_{L}+N_{M}+N_{H}=1$ employment will be determined by technology alone and given by:

$$
\begin{aligned}
& N_{L}=\frac{a_{H}}{a_{L}+a_{H}+a_{L} a_{H}} \\
& N_{H}=\frac{a_{L}}{a_{L}+a_{H}+a_{L} a_{H}}
\end{aligned}
$$

so that there will be job polarization with more rapid employment growth at the top if $a_{H}>a_{L}>0$ which might be the case if technical change radically increases the productivity of middling labor and slightly increases that of low-skill labor.

Now consider a more general model. Assume there is a constant returns to scale production function in the 3 types of labor (think of other inputs such as capital as being concentrated out of this) that we denote by:

$$
Y=F\left(A_{L} N_{L}, A_{M} N_{M}, A_{H} N_{H}\right)
$$

where the $A_{i}$ represents labor-augmenting technical progress for labor of type i. Let us define the employment of skill $\mathrm{i}$ in efficiency units as:

$$
\tilde{N}_{i}=A_{i} N_{i}
$$

and the cost per efficiency unit of labor of skill $i$ as:

$$
\tilde{W}_{i}=W_{i} / A_{i}
$$

where $W_{i}$ is the wage of labor of skill $\mathrm{i}$.

Associated with the production function in (9) will be a cost function that, given the assumption of constant returns to scale can be written as:

$$
C=C\left(\tilde{W}_{L}, \tilde{W}_{M}, \tilde{W}_{H}\right) Y
$$

\footnotetext{
${ }^{13}$ Matters would be easier if we only had to explain the rise in employment of low-skill relative to middling employment as part of the increase in the high-skill workers comes from those who were initially middling workers and it is possible that the net result is a fall in middling workers that is larger than the fall in low-skill workers resulting in a rise in the supply of low-skill relative to middling workers.
} 
and, given that the cost function must be homogeneous of degree 1 in its arguments, we can write this as:

$$
C=\tilde{W}_{M} C\left(\tilde{w}_{L}, 1, \tilde{w}_{H}\right) Y=\tilde{W}_{M} c\left(\tilde{w}_{L}, \tilde{w}_{H}\right) Y
$$

Now, by Shephard's Lemma we will have that the output-constant demands for efficiency units of labor of different skills will be given by:

$$
\begin{gathered}
\tilde{N}_{L}=c_{L}\left(\tilde{w}_{L}, \tilde{w}_{H}\right) Y \\
\tilde{N}_{M}=\left[c\left(\tilde{w}_{L}, \tilde{w}_{H}\right)-\tilde{w}_{L} c_{L}\left(\tilde{w}_{L}, \tilde{w}_{H}\right)-\tilde{w}_{H} c_{H}\left(\tilde{w}_{L}, \tilde{w}_{H}\right)\right] Y \\
\tilde{N}_{H}=c_{H}\left(\tilde{w}_{L}, \tilde{w}_{H}\right) Y
\end{gathered}
$$

from which one can derive the following expressions for the demand for low and high skill labor relative to middle skill labor (in efficiency units):

$$
\begin{aligned}
& \ln \left(\tilde{n}_{L}\right)=\ln \left[c_{L}\left(\tilde{w}_{L}, \tilde{w}_{H}\right)\right]-\ln \left[c\left(\tilde{w}_{L}, \tilde{w}_{H}\right)-\tilde{w}_{L} c_{L}\left(\tilde{w}_{L}, \tilde{w}_{H}\right)-\tilde{w}_{H} c_{H}\left(\tilde{w}_{L}, \tilde{w}_{H}\right)\right] \\
& \ln \left(\tilde{n}_{H}\right)=\ln \left[c_{H}\left(\tilde{w}_{L}, \tilde{w}_{H}\right)\right]-\ln \left[c\left(\tilde{w}_{L}, \tilde{w}_{H}\right)-\tilde{w}_{L} c_{L}\left(\tilde{w}_{L}, \tilde{w}_{H}\right)-\tilde{w}_{H} c_{H}\left(\tilde{w}_{L}, \tilde{w}_{H}\right)\right]
\end{aligned}
$$

Now let us totally differentiate these two equations. First, equation (17):

$$
d \ln \left(\tilde{n}_{L}\right)=\frac{c_{L L} d \tilde{w}_{L}+c_{L H} d \tilde{w}_{H}}{c_{L}}+\frac{\tilde{w}_{L}\left[c_{L L} d \tilde{w}_{L}+c_{L H} d \tilde{w}_{H}\right]+\tilde{w}_{H}\left[c_{L H} d \tilde{w}_{L}+c_{H H} d \tilde{w}_{H}\right]}{c\left(\tilde{w}_{L}, \tilde{w}_{H}\right)-\tilde{w}_{L} c_{L}\left(\tilde{w}_{L}, \tilde{w}_{H}\right)-\tilde{w}_{H} c_{H}\left(\tilde{w}_{L}, \tilde{w}_{H}\right)}
$$

To simplify this expression let us define the share of labor of skill i as:

$$
s_{i}=\frac{\tilde{w}_{i} c_{i}}{c}
$$

and the elasticity of substitution between labor of skill $i$ and skill $j$ as:

$$
\sigma_{i j}=\frac{c c_{i j}}{c_{i} c_{j}}
$$

Then, after some re-arrangement one can write (19) as:

$$
\begin{aligned}
d \ln \left(\tilde{n}_{L}\right) & =s_{L} \sigma_{L L} d \ln \left(\tilde{w}_{L}\right)+s_{H} \sigma_{L H} d \ln \left(\tilde{w}_{H}\right) \\
+ & \frac{s_{L}\left(s_{L} \sigma_{L L} d \ln \left(\tilde{w}_{L}\right)+s_{H} \sigma_{L H} d \ln \left(\tilde{w}_{H}\right)\right)+s_{H}\left(s_{L} \sigma_{L H} d \ln \left(\tilde{w}_{L}\right)+s_{H} \sigma_{H H} d \ln \left(\tilde{w}_{H}\right)\right)}{1-s_{L}-s_{H}}
\end{aligned}
$$

which can be written as:

$$
d \ln \left(\tilde{n}_{L}\right)=\frac{s_{L}\left[\sigma_{L L}+s_{H}\left(\sigma_{L H}-\sigma_{L L}\right)\right] d \ln \left(\tilde{w}_{L}\right)+s_{H}\left[\sigma_{H H}+s_{H}\left(\sigma_{L H}-\sigma_{H H}\right)\right] d \ln \left(\tilde{w}_{H}\right)}{1-s_{L}-s_{H}}
$$

Manipulation of the equation for the relative employment of high-skill labor, (18), leads to an expression analogous to (23):

$$
d \ln \left(\tilde{n}_{H}\right)=\frac{s_{L}\left[\sigma_{L L}+s_{L}\left(\sigma_{L H}-\sigma_{L L}\right)\right] d \ln \left(\tilde{w}_{L}\right)+s_{H}\left[\sigma_{H H}+s_{L}\left(\sigma_{L H}-\sigma_{H H}\right)\right] d \ln \left(\tilde{w}_{H}\right)}{1-s_{L}-s_{H}}
$$

We can represent this is matrix form as:

$$
d \ln (\tilde{n})=-\Sigma d \ln (\tilde{w})=-\Sigma d \ln (w)+\Sigma d \ln (a)
$$


where $\ln (n)$ is a column vector of $\ln \left(n_{L}\right)$ and $\ln \left(n_{H}\right)$ etc. Using (10) and (11) and using the fact that $N_{L}+N_{M}+N_{H}=1$ this can be converted to a relationship between change in the employment shares of low- and high-skill labor and actual relative wages of the form:

$$
d \ln (N)=B^{-1}[-\Sigma d \ln (w)+(\Sigma-I) d \ln (a)]
$$

where $B=\left(\begin{array}{cc}1+n_{L} & n_{H} \\ n_{L} & 1+n_{H}\end{array}\right)$. As in the simple Leontief example, it is not hard to find technology shocks that, for fixed relative wages, lead to job polarization. But, to analyse what is happening in the labor market as a whole we also need to model the supply of labor.

\section{The Response to Changes in Technology}

Assuming that the supply of labor different skill levels simply depends on relative (and not absolute) wages we can derive:

$$
d \ln (N)=E d \ln (w)
$$

where $E$ is the matrix of own-wage and cross-wage labor supply elasticities. We allow all relative wages to potentially affect the relative supply of a particular skill level. Combining (26) and (27) we have the following reduced-form expressions for the changes in relative wages and employment wages in response to technology shocks:

$$
d \ln (w)=\left(E+B^{-1} \Sigma\right)^{-1} B^{-1}(\Sigma-1) d \ln (A)
$$

and:

$$
d \ln (N)=E\left(E+B^{-1} \Sigma\right)^{-1} B^{-1}(\Sigma-1) d \ln (A)
$$

We know what has happened in the data, namely $d \ln \left(N_{L}\right)>0, d \ln \left(N_{H}\right)>0$ (the job polarization) and $d \ln \left(w_{L}\right)<0, d \ln \left(w_{H}\right)>0$ (rising wage inequality) and the question is whether we can find a plausible technology shock and parameter values to make this the outcome of a simple supply and demand model.

As discussed above the problem comes from thinking about the first line of the supply equation (27):

$$
d \ln \left(N_{L}\right)=e_{L L} d \ln \left(w_{L}\right)+e_{L H} d \ln \left(w_{H}\right)
$$

We would expect that $e_{L L}>0$ and $e_{L H}<0$ so that an increase in the wage of the low skill relative to the middling skill results in an increase in the supply of low relative to middling skill workers. But a stable labor supply curve cannot then explain what is happening - one needs some 'backward-bending' element to the supply curve or that an increase in the high-skill wage raises the supply of low-skill workers. Neither of these seems particularly attractive. 


\section{CENTRE FOR ECONOMIC PERFORMANCE \\ Recent Discussion Papers}

603 Nan-Kuang Chen

Hsiao-Lei Chu

602 Ricardo Peccei

Helen Bewley

Howard Gospel

Paul Willman

601 Andy Charlwood

600 Christopher A. Pissarides

599 Stephen Bond

Dietmar Harhoff

John Van Reenen

598 Michael Storper

Anthony J. Venables

597 Stephen Gibbons

Alan Manning

596 Paul Gregg

Maria Gutiérrez-

Domènech

Jane Waldfogel

595 Stephen Bond

Dietmar Harhoff

John Van Reenen

594 Andrew B. Bernard

Stephen Redding

Peter K. Schott

593 Anthony J. Venables

592 Sylvie Charlot Gilles Duranton
Collateral Value and Forbearance Lending

Is it Good To Talk? Information Disclosure and Organisational Performance in the UK Incorporating evidence submitted on the DTI discussion paper 'High Performance Workplaces Informing and Consulting Employees'

The Anatomy of Union Decline in Britain 1990-1998

Unemployment in Britain: A European Success Story

Corporate R\&D and Productivity in Germany and the United Kingdom

Buzz: Face-to-Face Contact and the Urban Economy

The Incidence of UK Housing Benefit: Evidence from the 1990s Reforms

The Employment of Married Mothers in Great

Britain: 1974-2000

Investment, $\mathrm{R} \& \mathrm{D}$ and Financial Constraints in Britain and Germany

Product Choice and Product Switching

Spatial Disparities in Developing Countries: Cities, Regions and International Trade

Communication Externalities in Cities 
591 Paul Willman

Alex Bryson

Rafael Gomez

590 Marco Manacorda

589 Alex Bryson

Rafael Gomez

588 Henry G. Overman

L. Alan Winters

587 Pierre-Philippe Combes

Henry G. Overman

586 Henry G. Overman

585 A. B. Bernard

J. Bradford Jensen

P. K. Schott

584 A. B. Bernard

J. Bradford Jensen

P. K. Schott

583 S. Wood

S. Moore

582 T. Kirchmaier

581 C. Dougherty

$580 \quad$ S. Burgess

D. Mawson

579 S. Nickell
Why Do Voice Regimes Differ?

Child Labor and the Labor Supply of Other

Household Members: Evidence from 1920 America

Why Have Workers Stopped Joining Unions?

Trade Shocks and Industrial Location: the Impact of EEC Accession on the UK

The Spatial Distribution of Economic Activities in the European Union

Can We Learn Anything from Economic Geography Proper?

Falling Trade Costs, Heterogeneous Firms and Industry Dynamics

Survival of the Best Fit: Exposure to Low-Wage

Countries and the (Uneven) Growth of U.S.

Manufacturing Plants

Reviewing the Statutory Union Recognition (ERA 1999)

Corporate Restructuring and Firm Performance of British and German Non-Financial Firms

Why Is the Rate of Return to Schooling Higher for Women than for Men?

Aggregate Growth and the Efficiency of Labour

Reallocation

Poverty and Worklessness in Britain 